University of Wollongong

Research Online

Faculty of Engineering and Information

Faculty of Engineering and Information

Sciences - Papers: Part B

Sciences

2018

Compressive behaviour of partially FRP confined concrete: Experimental observations and assessment of the stress-strain models

Weiqiang Wang

University of Technology Sydney,ww674@uowmail.edu.au

M Neaz Sheikh

University of Wollongong, msheikh@uow.edu.au

Ali Qasim Al-Baali

University of Wollongong, aqlab865@uowmail.edu.au

Muhammad N. S Hadi

University of Wollongong, mhadi@uow.edu.au

Follow this and additional works at: https://ro.uow.edu.au/eispapers1

Part of the Engineering Commons, and the Science and Technology Studies Commons

Research Online is the open access institutional repository for the University of Wollongong. For further information contact the UOW Library: research-pubs@uow.edu.au 


\title{
Compressive behaviour of partially FRP confined concrete: Experimental observations and assessment of the stress-strain models
}

\begin{abstract}
This study provides new insight on the compressive behaviour of partially fibre reinforced polymer (FRP) confined concrete with either strain-hardening or strain-softening responses. Fully FRP confined concrete, partially FRP confined concrete with different strip gaps, and unconfined concrete were tested under axial compression. Four types of axial load-axial deformation behaviours were observed for specimens with different strip gaps. Even though a high volumetric ratio of FRP was applied, the confinement effectiveness was negligible when the strip gap exceeded the diameter of the specimens. Moreover, the axial stress-axial strain behaviours of wrapped and non-wrapped concrete were observed to be different, and significant strain localization was observed within the non-wrapped region. Based on the experimental observations and an extensive literature review, a confinement effectiveness coefficient was proposed for partially FRP confined concrete. A stress-strain model was then developed by considering the proposed confinement effectiveness coefficient. The developed stress-strain model provided better predictions than other existing stress-strain models.
\end{abstract}

\section{Keywords}

compressive, concrete:, behaviour, experimental, observations, assessment, stress-strain, models, partially, frp, confined

\section{Disciplines}

Engineering | Science and Technology Studies

\section{Publication Details}

Wang, W., Sheikh, M. Neaz., Al-Baali, A. Q. \& Hadi, M. N. S. (2018). Compressive behaviour of partially FRP confined concrete: Experimental observations and assessment of the stress-strain models. Construction and Building Materials, 192 785-797. 
Compressive behaviour of partially FRP confined concrete: Experimental observations and assessment of the stress-strain models

\section{(1)}

Weiqiang Wang ${ }^{\mathrm{a}}$, M. Neaz Sheikh ${ }^{\mathrm{b}}$, Ali Q. Al-Baali ${ }^{\mathrm{b}}$, Muhammad N. S. Hadi ${ }^{\mathrm{b}, *}$

${ }^{a}$ Centre for Built Infrastructure Research, School of Civil and Environmental Engineering, University of Technology Sydney, NSW 2007, Australia

${ }^{\mathrm{b}}$ School of Civil, Mining and Environmental Engineering, University of Wollongong, NSW 2522, Australia

\footnotetext{
* Corresponding author.
}

Weiqiang.Wang@uts.edu.au (W. Wang); msheikh@uow.edu.au (M.N. Sheikh); aqlab865@uowmail.edu.au (A.Q. Al-Baali); mhadi@uow.edu.au (M.N.S. Hadi). 


\section{Compressive behaviour of partially FRP confined concrete: Experimental observations and assessment of the stress-strain models}

Abstract: This study provides new insight on the compressive behaviour of partially fibre reinforced polymer (FRP) confined concrete with either strain-hardening or strain-softening responses. Fully FRP confined concrete, partially FRP confined concrete with different strip gaps, and unconfined concrete were tested under axial compression. Four types of axial loadaxial deformation behaviours were observed for specimens with different strip gaps. Even though a high volumetric ratio of FRP was applied, the confinement effectiveness was negligible when the strip gap exceeded the diameter of the specimens. Moreover, the axial stress-axial strain behaviours of wrapped and non-wrapped concrete were observed to be different, and significant strain localization was observed within the non-wrapped region. Based on the experimental observations and an extensive literature review, a confinement effectiveness coefficient was proposed for partially FRP confined concrete. A stress-strain model was then developed by considering the proposed confinement effectiveness coefficient. The developed stress-strain model provided better predictions than other existing stress-strain models.

Keywords: FRP; Partial wrapping; Concrete; Strain localization; Stress-strain model. 


\section{INTRODUCTION}

Due to the advantages of high strength and stiffness to weight ratios as well as superior corrosion resistance, fibre reinforced polymer (FRP) has been extensively used in recent years to improve the compressive, flexural, and shear behaviours of concrete members [1-6]. One popular application of FRP is to provide confinement to concrete columns [7-15]. Both experimental and analytical studies have proven that the FRP confinement can enhance the strength and ductility of concrete under compressive loadings. Several stress-strain models were developed for FRP confined concrete for circular or non-circular sections [1-2, 16-17], which led to an adequate understanding of the compressive behaviour of FRP confined concrete.

Even though many studies were conducted on fully FRP confined concrete, only a small number of studies focused on partially FRP confined concrete [11, 18-22]. Partial FRP wrapping onto concrete columns requires less FRP material and can be applied easier and faster than full FRP wrapping [20]. Also, for existing deficient concrete columns with sparse steel ties, the performance of the columns is expected to be improved by partial FRP wrapping in between the sparse steel ties, since the local buckling of longitudinal steel bars can be effectively constrained [21]. Moreover, partial FRP wrapping onto the deteriorated part of the existing concrete columns can significantly increase the ultimate capacities of the columns without the necessity of wrapping FRP throughout the whole column [23].

Even though partial FRP wrapping has been considered promising in some applications, there is a lack of knowledge on the compressive behaviour of partially FRP confined concrete. Most of the existing studies were mainly focused on the compressive behaviour of partially FRP confined concrete with relatively small FRP strip gaps, in which case a strain-hardening 
response is more likely to occur. Only a few studies provided adequate information on partially FRP confined concrete with strain-softening response [11, 20-21]. On the other hand, it is widely accepted that the confinement effectiveness of partially FRP confined concrete is less than that of fully FRP confined concrete [20-21]. Several studies adopted a confinement effectiveness coefficient, $k_{e}$, to account for the reduced confinement effect for partially confined concrete $[11,18-21,24,25]$. Different $k_{e}$ values were suggested in several studies. The suggested $k_{e}$ values were obtained mostly based on the regression analysis of test results from steel confined concrete [26-29]. Therefore, direct application of the suggested $k_{e}$ values may be inappropriate for concrete confined with FRP. Moreover, the mainstream design standards regarding FRP confined concrete do not provide predictions of the ultimate strength and ultimate strain for partially FRP confined concrete [30-32]. The FIB [33] suggested a stress-strain model to predict the performance of partially FRP confined concrete, which was proposed by Spoelstra and Monti in 1999 [34]. Afterwards, a significant amount of research on FRP confinement was carried out in recent years and more accurate stress-strain models were proposed for fully FRP confined concrete [16]. On the other hand, research on stressstrain models for partially FRP confined concrete was limited $[11,20]$. Therefore, research investigations for more precise stress-strain models are imperative for partially FRP confined concrete under compressive loading.

This study is concerned with the compressive behaviour of partially FRP confined concrete with either strain-hardening or strain-softening responses. An experimental program was first carried out to investigate the performance of partially FRP confined concrete with varying strip gaps. The axial load-axial deformation behaviour of specimens, axial stress-axial strain behaviours of both wrapped and non-wrapped concrete was investigated. Based on the 
experimental investigations and an extensive review of literature, a confinement effectiveness coefficient, $k_{e}$, was proposed for partially FRP confined concrete. Afterwards, a stress-strain model was developed by considering the proposed confinement effectiveness coefficient, $k_{e}$. A new database was compiled from available literature and employed to assess the existing stress-strain models of partially FRP confined concrete.

\section{EXPERIMENTAL PROGRAM}

\subsection{Design of Experiments}

A total of 18 concrete specimens with $100 \mathrm{~mm}$ diameter and $200 \mathrm{~mm}$ height were cast and tested under axial compression. Fully FRP confined concrete, partially FRP confined concrete with different strip gaps in the middle of the specimens (strip gap $s=25 \mathrm{~mm}, 35 \mathrm{~mm}, 50 \mathrm{~mm}$, $75 \mathrm{~mm}, 100 \mathrm{~mm}, 125 \mathrm{~mm}$, and $150 \mathrm{~mm}$ ), and unconfined concrete were tested. The detailed FRP wrapping configurations are shown in Fig. 1. It is noted that this partial FRP wrapping configuration was different from a typical implementation of partial FRP wrapping, where discrete or continuous FRP strips were wrapped around the circumference of specimens. However, this partial wrapping configuration was used in Campione et al. [19] and reliable experimental results were obtained. The volumetric ratio $\left(\rho_{f}\right)$ of FRP was identical for both fully and partially FRP confined concrete, which was mainly to investigate the sole influence of strip gap on the confinement effectiveness of partially FRP confined concrete. For fully FRP confined concrete, three layers of carbon fibre reinforced polymer (CFRP) were wrapped with a volumetric ratio of 0.02 . A high volumetric ratio of FRP was applied to ensure that the confinement effectiveness can be observed even for specimens with relatively large strip gaps. The CFRP was chosen since it can provide higher confinement than glass fibre reinforced polymer (GFRP) or aramid fibre reinforced polymer (AFRP). Also, to ensure higher 
confinement, small specimens $(100 \mathrm{~mm} \times 200 \mathrm{~mm})$ were chosen for the experiment. For each wrapping configuration, two identical concrete specimens were tested. Table 1 lists the specimens tested in this study. The specimens have been labelled as: (a) "S" and the number afterwards indicate the gap between the FRP strips; and (b) "I" or "II" indicates the order of the two identical specimens. For example, Specimen "S50-I" refers to the first specimen of partially FRP confined concrete with 50 mm strip gap.

\subsection{Specimen Preparation and Material Properties Tests}

The CFRP sheet used in this study was supplied by Nanjing Hitech Composites CO., LTD [35]. The original width of CFRP sheet was $100 \mathrm{~mm}$ and the thickness was $0.167 \mathrm{~mm}$ per layer. In order to obtain the required width of CFRP strip, each CFRP strip was precisely cut from the original CFRP sheet using a pair of scissors. First, the total number of fibre strands in the original width of CFRP sheet was counted (37 fibre strands). Second, the width of each fibre strand was calculated as the total width divided by the total number of fibre strands $(2.70 \mathrm{~mm}$ per fibre strand). Third, the required number of fibre strands was cut from the CFRP sheet along the fibre direction based on the required width of CFRP strip. The cutting of CFRP strip from the original CFRP sheet was conducted carefully to ensure that the fibre strands along the cutting edge would not get damaged during the cutting. A measuring tape was then used to measure the required length of CFRP strip. It is noted that for specimens with large strip gaps, the required length of CFRP strips was quite large (e.g., 12 layers of CFRP strip was wrapped onto specimens with $150 \mathrm{~mm}$ strip gap).

Normal strength concrete with a design compressive strength of $30 \mathrm{MPa}$ was used for casting the specimens. The concrete was supplied by a local concrete provider with a maximum aggregate size of $10 \mathrm{~mm}$. After 28 days of standard curing, the concrete specimens were 
wrapped with different layers of FRP strips. A mixture of epoxy resin and hardener at a ratio of 5:1 was used as the adhesive. Before the first layer of CFRP strip was wrapped, the adhesive was evenly spread onto the surface of the specimen and then CFRP strip was wrapped onto the surface with the fibres oriented in the hoop direction. After the first layer was wrapped, the adhesive was evenly spread onto the surface of the first layer of CFRP strip and the second layer was continuously wrapped. The remaining layers of CFRP strips were wrapped in an equivalent manner. An overlap of $100 \mathrm{~mm}$ was ensured in the last layer of CFRP strips.

Compression tests at 28 days showed that the average compressive strength of the concrete was $32 \mathrm{MPa}$. The tensile properties of CFRP were tested according to ASTM D7565 [36]. Five CFRP coupons with $25 \mathrm{~mm}$ width and $250 \mathrm{~mm}$ length were prepared and tested. For each coupon, three layers of CFRP were glued together using epoxy resin. The coupons were capped at both ends by aluminium plates. Detailed description of the test can be found in Pham et al. [20]. The average nominal thickness of the coupons was $1.18 \mathrm{~mm}$, and the average tensile strength of CFRP was $1674 \mathrm{MPa}$ with an average ultimate strain of 0.016 .

\subsection{Test Setup and Instrumentation}

To investigate the axial and hoop strain distributions of the FRP strips, strain gauges were attached onto the middle of the FRP strips and evenly distributed away from the overlap zone. The gauge length of the strain gauges was $5 \mathrm{~mm}$. Two pairs of strain gauges were used for each specimen and each pair contained two strain gauges, one was attached in the axial direction and the other one was attached in the hoop direction. For fully FRP wrapped specimens, two pairs of strain gauges were attached onto the mid-height of the specimens with one pair $180^{\circ}$ away from the other pair (Fig. 1(a)). While for partially FRP wrapped specimens, one pair of 
strain gauges were attached onto the middle of the upper FRP strip and the other pair of strain gauges were attached onto the middle of the bottom FRP strip (Figs. 1(b)-(h)).

The compression tests for all the specimens were conducted using the Denison $5000 \mathrm{kN}$ testing machine. The specimens were capped with high-strength plaster on the top end to ensure uniform loading. Calibration was carried out to ensure that the specimens were placed at the centre of the testing machine. Two LVDTs were used to measure the deformation of the specimens in this study, as shown in Fig. 2. The tests were conducted as deflection controlled with a rate of $0.3 \mathrm{~mm} / \mathrm{min}$. The readings of the load, LVDTs, and strain gauges were recorded every second using a data logging system and were subsequently saved into a computer.

\section{Experimental Results and Analyses}

\subsection{Failure Modes}

The failure modes of specimens with varying strip gaps are shown in Fig. 3. For fully wrapped specimens as well as partially wrapped specimens with relatively small strip gaps $(s=25 \mathrm{~mm}$, and $35 \mathrm{~mm}$ ), the failures were caused by the rupture of FRP. While for partially wrapped specimens with relatively large strip gaps ( $s \geq 50 \mathrm{~mm}$ ), the failures were caused by the crushing of concrete within the non-wrapped region. Inclined shear cracks were observed for partially wrapped specimens with $125 \mathrm{~mm}$ and $150 \mathrm{~mm}$ strip gaps. For partially wrapped specimens, the non-wrapped concrete began to crack and spall off after the unconfined compressive strength was approached. The non-wrapped concrete was continuously crushed, which resulted in a smaller gap between the FRP strips (Fig. 3(c)). It is also noted that for partially wrapped specimens with more than $35 \mathrm{~mm}$ strip gaps, the upper part of specimens could be easily removed from the specimens after the test, which indicated extensive concrete crushing within the non-wrapped region. However, the crushing of non-wrapped concrete for partially wrapped 
specimens with $25 \mathrm{~mm}$ strip gap was not significant and remained almost intact after the failure of the specimens, which indicated sufficient confinement provided by the FRP strips to the non-wrapped concrete.

\subsection{Axial Load-Axial Deformation Behaviour of Specimens}

Table 2 reports the test results of all specimens, where the peak load $P_{u}$, peak stress $f_{c c}$, corresponding axial deformation $\Delta_{u}$ and axial strain $\varepsilon_{c c}$, as well as the corresponding hoop strain of FRP strips $\varepsilon_{h, f r p}$, are presented. Figs. 4 (a) and (b) show the axial load-axial deformation ( $P-\Delta$, where $P$ indicates the axial load and $\Delta$ indicates the axial deformation) behaviours of all specimens. With the increase of strip gap, the performance of partially FRP confined concrete was significantly decreased. When the strip gap was more than $50 \mathrm{~mm}$, the partially FRP confined concrete experienced a strain-softening response, which indicated insufficient confinement. Furthermore, when the strip gap exceeded the diameter of the specimens ( $s=100 \mathrm{~mm}$ ), the confinement effectiveness was negligible, as also can be seen in Figs. 4 and 5. This observation can be validated by the readings of strain gauges at the peak load for specimens with large strip gaps ( $s \geq 100 \mathrm{~mm}$ ), as shown in Table 2. The axial and hoop strains of FRP strips at peak loads were around $0.2 \%$ and $0.04 \%$, respectively, for specimens with $100 \mathrm{~mm}, 125 \mathrm{~mm}$, and $150 \mathrm{~mm}$ strip gaps. As a result, the confinement effect was marginal and could not contribute to the increase in the strength. When the strip gaps were equal to or less than $50 \mathrm{~mm}$, the partially FRP confined concrete experienced a strain-hardening response, and the peak load increased significantly with the decrease of strip gaps. Fully FRP confined concrete obtained the highest peak load, while Specimen "S35-I" obtained the largest axial deformation at peak load. 
The axial load-axial deformation behaviours of partially FRP confined concrete can be categorized into four types. For Specimens "S25-I, II", an initial parabolic ascending branch, followed by a linear second ascending branch until failure, was observed (Type A). For Specimens "S35-I, II", after the initial parabolic ascending branch, a linear second ascending branch was observed. Afterwards, a smooth descending branch occurred, which was mainly due to the strength degradation of non-wrapped concrete. The descending branch was then followed by a linear third ascending branch until FRP rupture (Type B). One possible interpretation for the linear third ascending branch was that the non-wrapped concrete was seriously crushed and spalled off and hence the upper and bottom parts of the wrapped concrete were closer to each other, as evidenced by Fig. 3 (c). As a result, the confinement effect became more prominent due to the reduced strip gap, thus a strain-hardening response was observed again. For specimens with Types A and B behaviours, the failures were caused by the rupture of FRP strips.

For Specimens "S50-I, II", the axial load-axial deformation behaviour was similar to that of Specimens "S35-I, II" until reaching the peak load, after which a continuous descending branch until failure was observed (Type C). In this case, the non-wrapped concrete lost all the strength before the FRP strips could take effect again. While for specimens with relatively large strip gaps ( $s \geq 75 \mathrm{~mm}$ ), a steep descending branch until failure was observed after the initial ascending branch (Type D). Moreover, with the decrease of strip gap, the descending branch became more gradual. The occurrence of strain-softening response indicated that the confinement provided by the FRP strips could not be activated if the strip gap was larger than $75 \mathrm{~mm}$. For specimens with Types C, D behaviours, the failures were caused by the crushing of non-wrapped concrete. 
239 It should be noted that the size of the tested specimens was relatively small compared to the sizes of real columns. Although the size effect on FRP confined concrete was found insignificant in several previous studies [37-39], Jamatia and Deb [40] reported the existence of size effect on the behaviour of FRP confined concrete under axial compression. Hence, the experimental results presented in this study should be translated with caution for large-size FRP confined concrete columns. Moreover, the slenderness ratio of the specimens was 2 and the specimens were categorized as short columns. As a result, the influence of the slenderness ratio was not reflected in the test results.

\subsection{Axial Stress-Axial Strain Behaviour of Wrapped and Non-Wrapped Concrete}

The axial load-strain relationships for specimens with varying strip gaps ( $s=0 \mathrm{~mm}, 25 \mathrm{~mm}, 35$ specimens ( $s>100 \mathrm{~mm}$ ) were very similar to those of unconfined concrete. Moreover, only one pair of strain gauge readings were shown in Fig. 6, since some strain gauges were damaged during the test. All the strain gauges were attached onto the middle of FRP strips to investigate the strain distributions within the wrapped region.

Except for specimens with Type A behaviour $(s=0 \mathrm{~mm}$, and $25 \mathrm{~mm}$ ), unloading occurred within the wrapped region for specimens with Types B, C, and D behaviours ( $s=35 \mathrm{~mm}, 50$ $\mathrm{mm}, 75 \mathrm{~mm}$, and $100 \mathrm{~mm}$ ). The slope for the unloading path was almost equal to the slope of the initial ascending curve, which indicated a linear unloading path. With the increase of strip gaps, both the axial and hoop strains within the wrapped region were significantly decreased, thus less amount of confinement could be provided by FRP strips. For specimens with Types A, B, and C behaviours ( $s=0 \mathrm{~mm}, 25 \mathrm{~mm}, 35 \mathrm{~mm}$, and $50 \mathrm{~mm}$ ), the axial and hoop strains of 
FRP strips continued to increase beyond the unconfined compressive strength, indicating that sufficient confinement was provided for a strain-hardening response. In addition, the wrapped concrete was reloaded for specimens with $35 \mathrm{~mm}$ strip gap after the unloading (Fig. 6 (c)). For specimens with Type D behaviour ( $s=75 \mathrm{~mm}, 100 \mathrm{~mm}$ ), the axial and hoop strains within the wrapped region were slightly increased or continuously decreased after the peak load (Figs. 6 (e) and (f)). Therefore, the confinement was insufficient to sustain a strain-hardening response.

The average axial strain of the specimen was continuously increased during the test (deflection controlled). Therefore, if decrease of axial strain due to unloading was observed within the wrapped region, the axial strain within the non-wrapped region must continue to increase so that the average axial strain of the specimen can experience an overall increase. Based on the above observations, the axial stress-axial strain behaviour of partially FRP confined concrete (both wrapped and non-wrapped concrete) can be divided into four distinct categories based on the types of axial load-axial deformation behaviours. For specimens with Type A axial loadaxial deformation behaviour, the axial stress-axial strain curve represented a typical stressstrain curve which was similar to that of fully FRP confined concrete with strain-hardening response (Fig. 7 (a)). For specimens with Type B axial load-axial deformation behaviour, the wrapped concrete experienced an unloading and then reloading. The non-wrapped concrete experienced a continuous decrease in the stress (Fig. 7 (b)). Moreover, due to the strip gap reduction as mentioned above, the confinement effect was higher and thus a higher peak stress was obtained for the specimen. For specimens with Types C and D axial load-axial deformation behaviours, the wrapped concrete was unloaded while the non-wrapped concrete experienced a continuous strain softening after the peak stress. In these cases, the axial strains within the wrapped region and non-wrapped region began to vary significantly after the peak stress (Figs. 7 (c) and (d)). 
290 With the increase of FRP strip gaps, the axial stress-axial strain curves changed from Type A to D behaviours. Moreover, it was apparent that significant strain localization occurred within the non-wrapped region for specimens with Types B to D behaviours. Due to the lack of sufficient data, the possibility of strain localization for specimens with Type A behaviour was not verified. However, it is believed that strain localization also occurred for specimens with Type A behaviour. This can be qualitatively described by the fact that after the unconfined concrete strength was reached, non-wrapped concrete began to crack and spall off; therefore, the effective cross section area of non-wrapped concrete was decreased. On the other hand, the applied load was equal throughout the height of the specimen due to the force equilibrium. As a result, the axial stress of the non-wrapped concrete $\left(\sigma_{2}\right)$ was higher than that of wrapped concrete $\left(\sigma_{1}\right)$, as shown in Fig. 7 (a). The difference continued to increase since more and more within non-wrapped region for all types of partially FRP confined concrete.

\section{Discussions on Confinement Effectiveness}

Many studies adopted a confinement effectiveness coefficient, $k_{e}$, to account for the reduced confinement effect for partially confined concrete. The confinement effectiveness coefficient was found to be different in different studies and was obtained mostly based on the regression analysis of test results from steel confined concrete [26-27, 41-44]. Iyengar et al. [41] studied the stress-strain behaviour of normal strength concrete confined with steel spirals. The confinement was found to be effective only when the pitch of spirals was less than the diameter 
of the confined concrete. Afterwards, Martinez et al. [42] stated that the conclusion was also applicable for high strength concrete confined with steel spirals. A confinement effectiveness coefficient $(1-s / d)$ was suggested, in which $s$ indicates the vertical spacing between neighbouring steel spirals, and $d$ indicates the diameter of confined concrete [42]. By using this coefficient, a linear relationship exists between the strength increase and spacing to diameter ratio $(s / d)$. Nevertheless, several studies revealed that the strength increase is not proportional to the $s / d$ ratio for both actively and passively confined concrete [43-44]. As a result, inaccurate predictions could be obtained by using this confinement effectiveness coefficient. Ahmad and Shah [26] later investigated the influence of vertical steel hoop spacing on the stress-strain behaviour of concrete. It was observed that the confinement was negligible when the vertical spacing exceeded 1.25 times the diameter of the confined concrete, and a confinement effectiveness coefficient $(1-\sqrt{s / 1.25 d})$ was suggested.

Sheikh and Uzumeri [27] assumed that the reduced confinement effect between neighbouring transverse reinforcement can be considered through the arching action assumption: a parabola is assumed to separate the effectively confined concrete and ineffectively confined concrete, as shown in Fig. 8. The ineffectively confined concrete is assumed to receive no confinement, while the effectively confined concrete is assumed to be uniformly confined. Based on this assumption, a confinement effectiveness coefficient $(1-s \cdot \tan \theta / 2 d)^{2}$ was suggested for concrete confined by steel hoops. The arching angle $\theta$ was considered to be $45^{\circ}$, which was developed by the regression analysis of the experimental results. It is clear that the variation of arching angle $\theta$ can significantly influence the confinement effectiveness coefficient, especially for concrete confined with sparse transverse reinforcement [45]. Moreover, in addition to the arching angle $\theta$, the three other parameters $(\alpha, \gamma$ and $\beta)$ were also proposed in the regression 
analysis. Even though good prediction results could be obtained, the accuracy of this confinement effectiveness coefficient cannot be fully verified, since the close prediction may be achieved because of counteracting errors in the four different parameters [45]. By using this confinement effectiveness coefficient, the confinement could be neglected when the vertical spacing of transverse reinforcement is more than two times the diameter of confined concrete [43].

Few analytical studies also focused on the influence of spacing to diameter ratio $(s / d)$ on the confinement effectiveness of concrete columns [43-44, 46-48]. An elastic analytical solution was developed by Chen and Mau [46] for circular concrete columns with transverse reinforcement. The confinement effectiveness is quantified as a function of spacing to radius ratio ( $s / r$, in which $r$ indicates radius of confined concrete). The confinement effectiveness is virtually negligible when the vertical spacing between neighbouring transverse reinforcement is as large as the diameter of the confined concrete. Elastoplastic analysis was later carried out by Eid and Dancygier [43] to investigate the confinement effectiveness of circular columns with transverse reinforcement. It was reported that the confinement effectiveness can be observed only if the vertical spacing between neighbouring transverse reinforcement is less than the diameter of the confined concrete. Also, the comparisons between the analytical and experimental results indicate that the empirical arch assumption is limited to the practical range of vertical spacing between neighbouring transverse reinforcement on which it is based [43].

Based on the experimental observations as well as the review of existing literature, it is suggested that the widely used empirical arch assumption can also be adopted for partially FRP confined concrete [29, 43]. However, a confinement effectiveness coefficient needs to be 
proposed to represent the behaviour of passively/FRP confined concrete [43-44, 47-48]. In this

362 partially FRP confined concrete:

$$
\begin{gathered}
\frac{f_{c c}}{f_{c o}}=1+3.3 k_{f} \frac{f_{l, a}}{f_{c o}} \\
f_{l, a}=\frac{1}{2} \rho_{f} E_{f} \varepsilon_{h, r u p}
\end{gathered}
$$

378 where $f_{c c}$ is the ultimate compressive strength of confined concrete; $f_{c o}$ is the unconfined compressive strength of concrete; $\kappa_{\mathrm{f}}$ is the confinement effectiveness coefficient, which can be expressed as $(1-s / d)^{2}$ for partially FRP confined concrete; $f_{l, a}$ is the actual lateral 
confining pressure; $\rho_{f}$ is the volumetric ratio of FRP; $E_{f}$ is the elastic modulus of FRP; and $\varepsilon_{h, r u p}$ is the actual hoop rupture strain of FRP.

The ultimate strain model in Lam and Teng [1] is also extended to partially FRP confined concrete by introducing the proposed confinement effectiveness coefficient $k_{e}$ :

$$
\frac{\varepsilon_{c c}}{\varepsilon_{c o}}=1.75+12 k_{e}\left(\frac{f_{l, a}}{f_{c o}}\right)\left(\frac{\varepsilon_{h, r u p}}{\varepsilon_{c o}}\right)^{0.45}
$$

where $\varepsilon_{c c}$ is the ultimate compressive strain of confined concrete; and $\varepsilon_{c o}$ is the unconfined compressive strain of concrete.

\section{Assessment of Stress-strain Models}

\subsection{Experimental Database}

A database containing test results of 76 partially FRP confined concrete was compiled (Table 3). It is noted that for the short specimens tested in this study, the wrapping scheme was different from the typical wrapping scheme. Moreover, the test results may be influenced by the end constraints. Therefore, the current test data were not used in developing and assessing the stress-strain models in the subsequent section. In this database, the concrete and FRP properties, amount of FRP, FRP strip gap, FRP strip width, peak axial stress, and corresponding axial strain were included. The diameter of the specimens varied from 100 to $200 \mathrm{~mm}$. The unconfined concrete strengths varied from 23 to $54 \mathrm{MPa}$. All specimens were not internally reinforced. Types of FRP included CFRP, GFRP and Basalt Fibre Reinforced Polymer (BFRP), while 67 specimens were confined with CFRP. In all cases, the FRP was wrapped onto the specimens with the fibres in the hoop direction. During these tests, 62 specimens experienced strain-hardening response, while 14 specimens experienced strain-softening response. 
Fig. 9 shows the relationship between the strain efficiency factor $\left(\varepsilon_{h, r u p} / \varepsilon_{f r p}\right)$ and the actual confinement ratio $\left(k_{f} \cdot f_{l, a} / f_{c o}\right)$. A large scatter of the data was observed. The average strain efficiency factor was calculated to be 0.594 , which was close to the strain efficiency factor of 0.55 that was suggested by ACI 440.2R-08 [30]. Moreover, for lightly partially FRP confined concrete, premature hoop rupture is more likely to occur with much lower hoop strains than the nominal ultimate tensile strain. For example, the three specimens with less amount of FRP confinement failed with a maximum strain efficiency factor of 0.34 only.

\subsection{Statistical Methods of Verification}

The performance of the proposed stress-strain model was compared with the existing models listed in Table 4. As for the model proposed by Barros and Ferreira [11], only unconfined concrete strength within $16 \mathrm{MPa}$ to $32 \mathrm{MPa}$ can be evaluated. Therefore, Barros and Ferreira [11] model was evaluated by using the available test results (16-32 MPa) of the database. The accuracy was evaluated by using two statistical indicators: average absolute error (AAE) and mean square error (MSE). The AAE and MSE indicators are determined by Equations (4) and 419 (5), respectively:

$$
\begin{aligned}
A A E & =\frac{\sum_{i=1}^{N}\left|\frac{\operatorname{pre}_{i}-\exp _{i}}{\exp _{i}}\right|}{N} \\
M S E & =\frac{\sum_{i=1}^{N}\left(\frac{\operatorname{pre}_{i}-\exp _{i}}{\exp _{i}}\right)^{2}}{N}
\end{aligned}
$$

420 A total of 62 data points were plotted to assess the performance of existing strength models and the proposed strength model. Fig. 10 shows the comparisons between these selected strength models. Based on the two statistical indicators, the proposed strength model provides 
the best ultimate strength prediction, followed by the models of Pham et al. [20] and FIB [33].

424 It can also be seen that un-conservative predictions are obtained by using other existing models,

425

426

427 while a conservative prediction is obtained by using the proposed model. Based on the comparison results, it is evident that the Lam and Teng [1] model can be successfully extended to provide accurate ultimate strength predictions for partially FRP confined concrete, when appropriate confinement effectiveness coefficient is included.

Fig. 11 shows the comparisons between different ultimate strain models. In general, the prediction accuracy on the ultimate strain is significantly lower than the prediction accuracy on the ultimate strength. The proposed ultimate strain model provides the best ultimate strain prediction, followed by the FIB [33] model and Barros and Ferreira [11] model. Even though reasonable accuracy can be obtained by using FIB [33] model, it may not be appropriate to use this model for ultimate strain prediction, since the effective hoop rupture strain was not taken into consideration in the model, as shown in Table 4. Moreover, the existing ultimate strain models failed to capture the unique characteristic of partially FRP confined concrete, that is, strain localization within the non-wrapped regions. It is recommended that a more accurate ultimate strain model be proposed to account for the non-uniform strain distribution along the height of the partially FRP confined concrete.

\section{Conclusions}

Based on the experimental and analytical investigations presented in this study, the following conclusions can be drawn:

1. The failure modes of partially FRP confined concrete differ with different strip gaps. For specimens with relatively small strip gaps, the failures are caused by the rupture of FRP strips. 
446 For specimens with relatively large strip gaps, the failures are caused by the crushing of non$447 \quad$ wrapped concrete.

2. The performance of partially FRP confined concrete significantly decreases with the increase of the strip gap. When the strip gap exceeds the diameter of the specimens, the confinement effectiveness becomes negligible even though a high FRP volumetric ratio is applied.

3. Based on the value of the FRP strip gap, the axial load-axial deformation behaviours of partially FRP confined concrete can be categorized into four different types. Moreover, the axial stress-axial strain behaviours of wrapped and non-wrapped concrete are different. Stress unloading occurs within the wrapped region for specimens with relatively large strip gaps, and significant strain localization can be observed within the non-wrapped region.

4. A confinement effectiveness coefficient is proposed based on the experimental observations and an extensive literature review. Afterwards, a stress-strain model is developed by considering the proposed confinement effectiveness coefficient into the widely used Lam and Teng [1] model. The developed stress-strain model has been found to provide better predictions than other existing models.

\section{References}

462 [1] Lam, L., and Teng, J. G. Design-oriented stress-strain model for FRP-confined concrete. 463 Construction and Building Materials 2003; 17(6-7): 471-489.

464 [2] Lam, L., and Teng, J. G. Design-oriented stress-strain model for FRP-confined concrete in 465 rectangular columns. Journal of Reinforced Plastics and Composites 2003; 22(13): 1149-1186.

466 [3] Hawileh, R. A., Nawaz, W., Abdalla, J. A., and Saqan, E. I. Effect of flexural CFRP sheets 467 on shear resistance of reinforced concrete beams. Composite Structures 2015; 122: 468-476. 

Journal 2016; 113(3): 577-586.

[5] Meyer, M. R., Friedman, R. J., Del Schutte, H., Jr., and Latour, R. A., Jr. Long-term durability of the interface in FRP composites after exposure to simulated physiologic saline environments. Journal of Biomedical Materials Research 1994; 28(10): 1221-1231.

[6] Hawileh, R. A., Rasheed, H. A., Abdalla, J. A., and Al-Tamimi, A. K. Behavior of reinforced concrete beams strengthened with externally bonded hybrid fiber reinforced polymer systems. Materials \& Design 2014; 53: 972-982.

[7] Shahawy, M., Mirmiran, A. and Beitelman, T. Tests and modeling of carbon-wrapped concrete columns. Composites Part B: Engineering 2000; 31(6): 471-480.

[8] Wang, W., Sheikh, M. N., Hadi, M. N. S., Gao, D., and Chen, G. Behaviour of concreteencased concrete-filled FRP tube (CCFT) columns under axial compression. Engineering Structures 2017; 147: 256-268. concrete columns under different loading conditions. Journal of Composites for Construction 2016; 20(5): 04016034. axial compression. Thin-Walled Structures 2015; 95: 88-100. for concrete cylinders. Journal of Composites for Construction 2008; 12(2): 134-148. 
[12] Wang, W., Martin, P. R., Sheikh, M. N., and Hadi, M. N. S. Eccentrically loaded FRP confined concrete with different wrapping schemes. Journal of Composites for Construction 2018: accepted on $15^{\text {th }}$ June 2018.

[13] Wang, W., Wu, C., Liu, Z., and Si, H. Compressive behavior of ultra-high performance fiber-reinforced concrete (UHPFRC) confined with FRP. Composite Structures 2018; 204: 419-437.

[14] Hadi, M. N. S., and Widiarsa, I. B. R. Axial and flexural performance of square RC columns wrapped with CFRP under eccentric loading. Journal of Composites for Construction 2012; 16(6): 640-649.

[15] Hadi, M. N. S., Wang, W., and Sheikh, M. N. Axial compressive behaviour of GFRP tube reinforced concrete columns. Construction and Building Materials 2015; 81: 198-207.

[16] Ozbakkaloglu, T., Lim, J. C., and Vincent, T. FRP-confined concrete in circular sections: review and assessment of the stress-strain models. Engineering Structures 2013; 49: 10681088.

[17] Lim, J., and Ozbakkaloglu, T. Confinement model for FRP confined high-strength concrete. Journal of Composites for Construction 2014; 18(4): 04013058-1-04013058-19.

[18] Park, T. W., Na, U. J., Chung, L., and Feng, M. Q. Compressive behaviour of concrete cylinders confined by narrow strips of CFRP with spacing. Composites Part B: Engineering 2008; 39(7-8): 1093-1103.

[19] Campione, G., La Mendola, L., Monaco, A., Valenza, A., and Fiore, V. Behaviour in compression of concrete cylinders externally wrapped with basalt fibres. Composites Part B: Engineering 2015; 69: 576-586. 

circular concrete columns under axial compression. Journal of Composites for Construction 2015; 19(6): 04015015, 1-10.

514

[21] Triantafyllou, G. G., Rousakis, T. C., and Karabinis, A. I. Axially loaded reinforced concrete columns with a square section partially confined by light GFRP straps. Journal of Composites for Construction 2015; 19(1): 04014035, 1-15. confined by intermittent CFRP wraps. Composites Part B: Engineering 2016; 89: 85-95.

[23] Wei, H., Wu, Z., Guo, X., and Yi, F. Experimental study on partially deteriorated strength concrete columns confined with CFRP. Engineering Structures 2009; 31(10): 2495-2505.

[24] Saadatmanesh, H., Ehsani, M. R., and Li, M. W. Strength and ductility of concrete columns externally reinforced with fibre composite straps. ACI Structural Journal 1994; 91(4): 434-447.

[25] Wang, W., Sheikh, M. N., and Hadi, M. N. S. Axial compressive behaviour of concrete confined with polymer grid. Materials and Structures/Materiaux et Constructions 2016; 49(9): 3893-3908.

527

[26] Ahmad, S. H., and Shah, S. P. Stress-strain curves of concrete confined by spiral 528 reinforcement. ACI Journal Proceedings 1982; 79(6): 484-490.

[27] Sheikh, S., and Uzumeri, S. M. Analytical model for concrete confinement in tied columns. Journal of the Structural Division 1982; 108(ST12): 2703-2722. concrete. Journal of Structural Engineering 1988; 114(8): 1804-1826. 
533 [29] Teng, J. G., Xiao, Q. G., Yu, T., and Lam, L. Three-dimensional finite element analysis 534 of reinforced concrete columns with FRP and/or steel confinement. Engineering Structures $535 \quad 2015 ; 97: 15-28$.

536 [30] ACI. Guide for the design and construction of externally bonded FRP systems for 537 strengthening concrete structures. ACI 440.2 R-08 2008; Farmington Hills, MI.

[31] GB. Technical code for infrastructure application of FRP composites. GB 50608-10 2010;

539 Beijing, China.

540 [32] TR. Design guidance for strengthening concrete structures using fibre composite materials. 541 TR 55 2012; Concrete Society, Camberley, England.

542 [33] FIB (Fédération internationale du béton). Externally bonded FRP reinforcement for RC 543 structures. Bulletin 2001; 14, 138.

544 [34] Spoelstra, M. R., and Monti, G. FRP-confined concrete model, Journal of Composites for 545 Construction 1999; 3(3): 143-150.

546 [35] Nanjing Hitech Composites Co.,Ltd. CFRP. 〈http://www.hitechfrp.com/goods-show547 919.htm $>$ (Assessed on $1^{\text {st }}$ Jun 2018).

548 [36] ASTM. Standard test method for tensile properties of fibre reinforced polymer matrix 549 composites used for strengthening of civil structures. ASTM D7565 2010; West Conshohocken, 550 PA.

551 [37] Carey, S. A., and Harries, K. A. Axial behavior and modeling of confined small-, medium552 and large scale circular sections with carbon fiber-reinforced polymer jackets. ACI Structural 553 Journal 2005; 102(4): 596-604. 
554

555

556

557

558

559

560

561

562

563

564

565

566

567

568

569

570

571

572

573

574

[38] Elsanadedy, H. M., Al-Salloum, Y. A., Alsayed, S. H., and Iqbal, R. A. Experimental and numerical investigation of size effects in FRP-wrapped concrete columns. Construction and Building Materials 2012; 29: 56-72.

[39] Thériault, M., Neale, K. W., and Claude, S. Fiber-Reinforced Polymer-Confined Circular Concrete Columns: Investigation of Size and Slenderness Effects. Journal of Composites for Construction 2004; 8(4): 323-331.

[40] Jamatia, R., and Deb, A. Size Effect in FRP-Confined Concrete under Axial Compression. Journal of Composites for Construction 2017; 21(6): 04017045.

[41] Iyengar, K. T. S. R., Desayi, P., and Reddy, K. N. Stress-strain characteristics of concrete confined in steel binders. Magazine of Concrete Research 1970; 22(72): 173-184.

[42] Martinez, S., Nilson, A. H., and Slate, F. O. Spirally reinforced high-strength concrete columns. Journal of the American Concrete Institute 1984; 81(5): 431-442.

[43] Eid, R., and Dancygier, A. N. Confinement effectiveness in circular concrete columns. Engineering Structures 2006; 28(13): 1885-1896.

[44] Eid, R., Dancygier, A. N., and Paultre, P. Elastoplastic confinement model for circular concrete columns. Journal of Structural Engineering 2007; 133(12): 1821-1831.

[45] Wang, Y. C., and Restrepo, J. I. Investigation of concentrically loaded reinforced concrete columns confined with glass fibre-reinforced polymer jackets. ACI Structural Journal 2001; 98(3): 377-385.

[46] Chen, B., and Mau, S. T. Numerical simulation of behaviour of spirally reinforced columns. Journal of Structural Engineering 1990; 116(10): 2842-2861. 
575 [47] Eid, R., Dancygier, A. N., and Paultre, P. Stress-strain curve for concrete in circular 576 columns based on elastoplastic analysis. Materials and Structures/Materiaux et Constructions $577 \quad 2010 ; 43(1-2): 63-79$.

578 [48] Eid, R., and Paultre, P. Plasticity-based model for circular concrete columns confined with 579 fibre-composite sheets. Engineering Structures 2007; 29(12): 3301-3311.

580 [49] Wang, J. W. Test study on mechanical performance of C50 concrete cylinders confined 581 by CFRP under axial load. Master thesis 2010; Yanbian University, Yanbian, China.

582 [50] Yang, Y. W. Experimental research on durability of FRP confined load-bearing short 583 columns. Master thesis 2010; Shenzhen Graduate School of Harbin Institute of Technology, Shenzhen, China.

[51] Wu, G., Lü, Z. T., and Wu, Z. S. Strength and ductility of concrete cylinders confined with FRP composites. Construction and Building Materials 2006; 20(3): 134-148.

587

588

589

590

591

592

593

594 
605 Table 1. Test Matrix

606 Table 2. Experimental Results

607 Table 3. Collected Test Results of Partially FRP Confined Concrete

608 Table 4. Summary of Existing Stress-Strain Models for Partially FRP Confined Concrete 609 
624 List of Figures

625 Fig. 1. Wrapping configurations

626 Fig. 2. Test setup

627 Fig. 3. Failure modes

628 Fig. 4. Axial load-axial deformation behaviour of specimens

629 Fig. 5. Influence of s/D ratio on the ultimate load (Note: s/D indicates spacing to diameter 630 ratio, and $\mathrm{P} 2 / \mathrm{P} 1$ indicates load enhancement ratio)

631 Fig. 6. Axial load-strain relationships (strain gauges readings were taken from FRP strips)

632 Fig. 7. Axial stress-axial strain behaviours

633 Fig. 8. Partial confinement mechanism

634 Fig. 9. Hoop rupture strain of FRP with different effective confinement ratio

635 Fig. 10. Performance of models on ultimate strength prediction

636 Fig. 11. Performance of models on ultimate strain prediction 
640

641

642

643

644

645

646 Table 1. Test Matrix

\begin{tabular}{lccccc}
\hline Specimen & Strip width $w$ & Strip gap $s$ & $s / d$ & Number of FRP layers & FRP volumetric ratio $\rho_{f}$ \\
\hline S0-I, II & 100.0 & 0 & 0 & 3 & 0.02 \\
S25-I, II & 87.5 & 25 & 0.25 & 4 & 0.02 \\
S35-I, II & 82.5 & 35 & 0.35 & 4 & 0.02 \\
S50-I, II & 75.0 & 50 & 0.50 & 4 & 0.02 \\
S75-I, II & 62.5 & 75 & 0.75 & 5 & 0.02 \\
S100-I, II & 50.0 & 100 & 1.00 & 6 & 0.02 \\
S125-I, II & 37.5 & 125 & 1.25 & 8 & 0.02 \\
S150-I, II & 25.0 & 150 & 1.50 & 12 & 0.02 \\
S200-I, II & 0.0 & 200 & 2.00 & 0 & 0.00 \\
\hline S2
\end{tabular}

647

Note: $d$ is the diameter of specimen, and $s$ is the gap between FRP strips.

648

649

650

651 
652

653

654

655

656

657

658

659

660

661

662 Table 2. Experimental Results

\begin{tabular}{lcccccc}
\hline Specimens & $P_{u}(\mathrm{kN})$ & $f_{c c}(\mathrm{MPa})$ & $\Delta_{u}(\mathrm{~mm})$ & $\varepsilon_{c c}(\%)$ & $\varepsilon_{h, f r p}(\%)$ & $P-\Delta$ relationship \\
\hline S0-I & 1126 & 143.4 & 11.06 & 3.74 & 1.54 & $\mathrm{~A}$ \\
S0-II & 1036 & 131.9 & 11.41 & 3.51 & 1.52 & $\mathrm{~A}$ \\
S25-I & 871 & 110.1 & 10.52 & 2.52 & 1.20 & $\mathrm{~A}$ \\
S25-II & 825 & 105.0 & 10.54 & 2.30 & 1.21 & $\mathrm{~A}$ \\
S35-I & 695 & 88.5 & 31.45 & 1.46 & 1.23 & $\mathrm{~B}$ \\
S35-II & 643 & 81.9 & 28.90 & 1.62 & 1.24 & $\mathrm{~B}$ \\
S50-I & 367 & 46.7 & 3.26 & 0.31 & 0.20 & $\mathrm{C}$ \\
S50-II & 392 & 49.9 & 3.78 & 0.42 & 0.29 & $\mathrm{C}$ \\
S75-I & 326 & 41.5 & 1.10 & 0.21 & 0.05 & $\mathrm{D}$ \\
S75-II & 346 & 44.1 & 0.96 & 0.20 & 0.06 & $\mathrm{D}$ \\
S100-I & 332 & 42.3 & 0.76 & 0.24 & 0.04 & $\mathrm{D}$ \\
S100-II & 315 & 40.1 & 0.81 & 0.17 & 0.03 & $\mathrm{D}$ \\
S125-I & 319 & 40.6 & 0.98 & 0.32 & 0.05 & $\mathrm{D}$ \\
S125-II & 323 & 41.1 & 0.95 & 0.17 & 0.04 & $\mathrm{D}$ \\
S150-I & 313 & 39.9 & 0.75 & 0.25 & 0.04 & $\mathrm{D}$ \\
S150-II & 306 & 39.0 & 0.81 & 0.19 & 0.04 & $\mathrm{D}$ \\
S200-I & 278 & 35.4 & 0.83 & - & - & $\mathrm{D}$ \\
S200-II & 286 & 36.4 & 0.88 & - & - & $\mathrm{D}$ \\
\hline
\end{tabular}


663 Note: $P_{u}$ is the peak axial load; $f_{c c}$ is the peak axial stress; $\Delta_{u}$ is the axial deformation at peak $664 \operatorname{load} P_{u} ; \varepsilon_{c c}$ is the axial strain of FRP strips at peak stress $f_{c c} ; \varepsilon_{h, f r p}$ is the hoop strain of FRP 665 strips at peak stress $f_{c c} ; P$ is the axial load; and $\Delta$ is the axial deformation. 
Table 3. Collected Test Results of Partially FRP Confined Concrete

\begin{tabular}{|c|c|c|c|c|c|c|c|c|c|c|c|c|c|c|c|c|}
\hline $\begin{array}{c}\text { Number } \\
\text { of } \\
\text { specimens }\end{array}$ & Source of data & $H$ & $d$ & $f_{c o}$ & $\begin{array}{l}\mathcal{E}_{c o} \\
(\%)\end{array}$ & $\begin{array}{l}\text { Fibre } \\
\text { type }\end{array}$ & $t$ & $f_{f r p}$ & $E_{f r p}$ & $\begin{array}{c}\mathcal{E}_{f r p} \\
(\%)\end{array}$ & $\begin{array}{c}\varepsilon_{h, \text { rup }} \\
(\%)\end{array}$ & $w$ & $s$ & $\frac{f_{c c}}{f_{c o}}$ & $\frac{\varepsilon_{c c}}{\varepsilon_{c o}}$ & $\frac{f_{c u}}{f_{c o}}$ \\
\hline 1 & Pham et al. [20] & 300 & 150 & 54 & 0.23 & GFRP & 1.40 & 582 & 29.5 & 1.97 & 1.59 & 25 & 25 & 1.02 & 5.43 & 1.02 \\
\hline 2 & Pham et al. [20] & 300 & 150 & 54 & 0.23 & GFRP & 1.40 & 582 & 29.5 & 1.97 & 1.61 & 25 & 25 & 0.98 & 5.48 & 0.98 \\
\hline 3 & Pham et al. [20] & 300 & 150 & 54 & 0.23 & GFRP & 1.40 & 582 & 29.5 & 1.97 & 1.34 & 25 & 25 & 0.95 & 4.43 & 0.95 \\
\hline 4 & Pham et al. [20] & 300 & 150 & 54 & 0.23 & CFRP & 1.80 & 2157 & 133 & 1.62 & 1.18 & 25 & 25 & 1.59 & 6.87 & 1.59 \\
\hline 5 & Pham et al. [20] & 300 & 150 & 54 & 0.23 & CFRP & 1.80 & 2157 & 133 & 1.62 & 1.18 & 25 & 25 & 1.76 & 8.91 & 1.76 \\
\hline 6 & Pham et al. [20] & 300 & 150 & 54 & 0.23 & CFRP & 1.80 & 2157 & 133 & 1.62 & 1.42 & 25 & 25 & 1.78 & 9.22 & 1.78 \\
\hline 7 & Pham et al. [20] & 300 & 150 & 54 & 0.23 & CFRP & 2.70 & 2157 & 133 & 1.62 & 1.21 & 25 & 25 & 2.09 & 13.91 & 2.09 \\
\hline 8 & Pham et al. [20] & 300 & 150 & 54 & 0.23 & CFRP & 2.70 & 2157 & 133 & 1.62 & 1.29 & 25 & 25 & 2.19 & 14.13 & 2.19 \\
\hline 9 & Pham et al. [20] & 300 & 150 & 54 & 0.23 & CFRP & 2.70 & 2157 & 133 & 1.62 & 1.39 & 25 & 25 & 2.17 & 14.3 & 2.17 \\
\hline 10 & $\begin{array}{c}\text { Barros and } \\
\text { Ferreira [11] }\end{array}$ & 300 & 150 & 23 & 0.25 & CFRP & 0.18 & 3250 & 230 & 1.46 & 0.80 & 15 & 285 & 1.17 & 1.2 & 0.85 \\
\hline 11 & $\begin{array}{l}\text { Barros and } \\
\text { Ferreira [11] }\end{array}$ & 300 & 150 & 23 & 0.25 & CFRP & 0.35 & 3250 & 230 & 1.46 & 0.80 & 15 & 285 & 1.19 & 1.32 & 0.85 \\
\hline 12 & $\begin{array}{l}\text { Barros and } \\
\text { Ferreira [11] }\end{array}$ & 300 & 150 & 23 & 0.25 & CFRP & 0.53 & 3250 & 230 & 1.46 & 0.80 & 15 & 285 & 1.2 & 1.12 & 0.85 \\
\hline 13 & $\begin{array}{l}\text { Barros and } \\
\text { Ferreira [11] }\end{array}$ & 300 & 150 & 23 & 0.25 & CFRP & 0.70 & 3250 & 230 & 1.46 & 0.80 & 15 & 285 & 1.2 & 1.4 & 0.85 \\
\hline 14 & $\begin{array}{c}\text { Barros and } \\
\text { Ferreira [11] }\end{array}$ & 300 & 150 & 23 & 0.25 & CFRP & 1.06 & 3250 & 230 & 1.46 & 0.80 & 15 & 285 & 1.24 & 1.4 & 0.85 \\
\hline 15 & $\begin{array}{l}\text { Barros and } \\
\text { Ferreira [11] }\end{array}$ & 300 & 150 & 23 & 0.25 & CFRP & 0.17 & 3250 & 230 & 1.46 & 0.45 & 15 & 85 & 1.3 & 1.6 & 0.85 \\
\hline 16 & $\begin{array}{l}\text { Barros and } \\
\text { Ferreira [11] }\end{array}$ & 300 & 150 & 23 & 0.25 & CFRP & 0.35 & 3250 & 230 & 1.46 & 0.40 & 15 & 85 & 1.32 & 1.64 & 0.85 \\
\hline 17 & $\begin{array}{l}\text { Barros and } \\
\text { Ferreira [11] }\end{array}$ & 300 & 150 & 23 & 0.25 & CFRP & 0.53 & 3250 & 230 & 1.46 & 0.70 & 15 & 85 & 1.3 & 1.72 & 0.85 \\
\hline 18 & $\begin{array}{c}\text { Barros and } \\
\text { Ferreira [11] }\end{array}$ & 300 & 150 & 23 & 0.25 & CFRP & 0.70 & 3250 & 230 & 1.46 & 0.70 & 15 & 85 & 1.3 & 1.8 & 0.85 \\
\hline
\end{tabular}




\begin{tabular}{|c|c|c|c|c|c|c|c|c|c|c|c|c|c|c|c|c|}
\hline 19 & $\begin{array}{c}\text { Barros and } \\
\text { Ferreira [11] }\end{array}$ & 300 & 150 & 23 & 0.25 & CFRP & 1.06 & 3250 & 230 & 1.46 & 0.80 & 15 & 85 & 1.35 & 1.68 & 0.85 \\
\hline 20 & $\begin{array}{l}\text { Barros and } \\
\text { Ferreira [11] }\end{array}$ & 300 & 150 & 23 & 0.25 & CFRP & 0.18 & 3250 & 230 & 1.46 & 0.80 & 15 & 45 & 1.22 & 1.56 & 0.85 \\
\hline 21 & $\begin{array}{l}\text { Barros and } \\
\text { Ferreira [11] }\end{array}$ & 300 & 150 & 23 & 0.25 & CFRP & 0.35 & 3250 & 230 & 1.46 & 0.80 & 15 & 45 & 1.23 & 3.08 & 0.85 \\
\hline 22 & $\begin{array}{l}\text { Barros and } \\
\text { Ferreira [11] }\end{array}$ & 300 & 150 & 23 & 0.25 & CFRP & 0.53 & 3250 & 230 & 1.46 & 0.80 & 15 & 45 & 1.38 & 3.44 & 1.38 \\
\hline 23 & $\begin{array}{l}\text { Barros and } \\
\text { Ferreira [11] }\end{array}$ & 300 & 150 & 23 & 0.25 & CFRP & 0.70 & 3250 & 230 & 1.46 & 0.80 & 15 & 45 & 1.49 & 4 & 1.49 \\
\hline 24 & $\begin{array}{l}\text { Barros and } \\
\text { Ferreira [11] }\end{array}$ & 300 & 150 & 23 & 0.25 & CFRP & 1.06 & 3250 & 230 & 1.46 & 0.80 & 15 & 45 & 1.63 & 4.8 & 1.63 \\
\hline 25 & $\begin{array}{l}\text { Barros and } \\
\text { Ferreira [11] }\end{array}$ & 300 & 150 & 23 & 0.25 & CFRP & 0.53 & 3250 & 230 & 1.46 & 1.30 & 30 & 70 & 1.61 & 10.8 & 1.61 \\
\hline 26 & $\begin{array}{c}\text { Barros and } \\
\text { Ferreira [11] }\end{array}$ & 300 & 150 & 23 & 0.25 & CFRP & 0.88 & 3250 & 230 & 1.46 & 0.75 & 30 & 70 & 1.87 & 10.8 & 1.87 \\
\hline 27 & $\begin{array}{l}\text { Barros and } \\
\text { Ferreira [11] }\end{array}$ & 300 & 150 & 23 & 0.25 & CFRP & 1.23 & 3250 & 230 & 1.46 & 0.75 & 30 & 70 & 1.83 & 9.52 & 1.83 \\
\hline 28 & $\begin{array}{l}\text { Barros and } \\
\text { Ferreira [11] }\end{array}$ & 300 & 150 & 23 & 0.25 & CFRP & 0.53 & 3250 & 230 & 1.46 & 0.74 & 30 & 45 & 2.48 & 9.2 & 2.48 \\
\hline 29 & $\begin{array}{l}\text { Barros and } \\
\text { Ferreira [11] }\end{array}$ & 300 & 150 & 23 & 0.25 & CFRP & 0.88 & 3250 & 230 & 1.46 & 1.00 & 30 & 45 & 2.83 & 8.24 & 2.83 \\
\hline 30 & $\begin{array}{l}\text { Barros and } \\
\text { Ferreira [11] }\end{array}$ & 300 & 150 & 23 & 0.25 & CFRP & 0.53 & 3250 & 230 & 1.46 & 0.80 & 45 & 30 & 3.91 & 9.6 & 3.91 \\
\hline 31 & $\begin{array}{l}\text { Barros and } \\
\text { Ferreira [11] }\end{array}$ & 300 & 150 & 23 & 0.25 & CFRP & 0.88 & 3250 & 230 & 1.46 & 0.77 & 45 & 30 & 3.11 & 11 & 3.11 \\
\hline 32 & $\begin{array}{l}\text { Barros and } \\
\text { Ferreira [11] }\end{array}$ & 300 & 150 & 23 & 0.25 & CFRP & 1.23 & 3250 & 230 & 1.46 & 0.80 & 45 & 30 & & & \\
\hline 33 & $\begin{array}{l}\text { Barros and } \\
\text { Ferreira [11] }\end{array}$ & 300 & 150 & 23 & 0.25 & CFRP & 0.53 & 3250 & 230 & 1.46 & 1.20 & 60 & 40 & 2.89 & 10.8 & 2.89 \\
\hline 34 & $\begin{array}{l}\text { Barros and } \\
\text { Ferreira [11] }\end{array}$ & 300 & 150 & 23 & 0.25 & CFRP & 0.88 & 3250 & 230 & 1.46 & 0.65 & 60 & 40 & 3.46 & 11 & 3.46 \\
\hline 35 & $\begin{array}{l}\text { Barros and } \\
\text { Ferreira [11] }\end{array}$ & 300 & 150 & 23 & 0.25 & CFRP & 1.23 & 3250 & 230 & 1.46 & 0.64 & 60 & 40 & 3.61 & 11.4 & 3.61 \\
\hline 36 & $\begin{array}{l}\text { Barros and } \\
\text { Ferreira [11] }\end{array}$ & 300 & 150 & 16 & 0.24 & CFRP & 0.34 & 3539 & 232 & 1.53 & 0.77 & 45 & 30 & 1.66 & 5.07 & 1.66 \\
\hline
\end{tabular}




\begin{tabular}{|c|c|c|c|c|c|c|c|c|c|c|c|c|c|c|c|c|}
\hline 37 & $\begin{array}{c}\text { Barros and } \\
\text { Ferreira [11] }\end{array}$ & 300 & 150 & 16 & 0.24 & CFRP & 0.57 & 3539 & 232 & 1.53 & 0.75 & 45 & 30 & 2.09 & 7.2 & 2.09 \\
\hline 38 & $\begin{array}{l}\text { Barros and } \\
\text { Ferreira [11] }\end{array}$ & 300 & 150 & 16 & 0.24 & CFRP & 0.34 & 3539 & 232 & 1.53 & 0.64 & 60 & 40 & 1.64 & 5.46 & 1.64 \\
\hline 39 & $\begin{array}{c}\text { Barros and } \\
\text { Ferreira [11] }\end{array}$ & 300 & 150 & 16 & 0.24 & CFRP & 0.57 & 3539 & 232 & 1.53 & 0.84 & 60 & 40 & 2.08 & 8.48 & 2.08 \\
\hline 40 & $\begin{array}{l}\text { Barros and } \\
\text { Ferreira [11] }\end{array}$ & 300 & 150 & 16 & 0.24 & CFRP & 0.53 & 3250 & 230 & 1.46 & 0.80 & 45 & 30 & 3.17 & 12.21 & 3.17 \\
\hline 41 & $\begin{array}{c}\text { Barros and } \\
\text { Ferreira [11] }\end{array}$ & 300 & 150 & 16 & 0.24 & CFRP & 0.88 & 3250 & 230 & 1.46 & 0.86 & 45 & 30 & 3.96 & 16 & 3.96 \\
\hline 42 & $\begin{array}{l}\text { Barros and } \\
\text { Ferreira [11] }\end{array}$ & 300 & 150 & 16 & 0.24 & CFRP & 0.53 & 3250 & 230 & 1.46 & 1.02 & 60 & 40 & 2.62 & 12.15 & 2.62 \\
\hline 43 & $\begin{array}{l}\text { Barros and } \\
\text { Ferreira [11] }\end{array}$ & 300 & 150 & 16 & 0.24 & CFRP & 0.88 & 3250 & 230 & 1.46 & 0.86 & 60 & 40 & 3.51 & 20.08 & 3.51 \\
\hline 44 & $\begin{array}{l}\text { Barros and } \\
\text { Ferreira [11] }\end{array}$ & 300 & 150 & 23 & 0.25 & CFRP & 0.34 & 3539 & 232 & 1.53 & 0.67 & 45 & 30 & 1.37 & 3.14 & 1.37 \\
\hline 45 & $\begin{array}{l}\text { Barros and } \\
\text { Ferreira [11] }\end{array}$ & 300 & 150 & 23 & 0.25 & CFRP & 0.57 & 3539 & 232 & 1.53 & 0.73 & 45 & 30 & 1.81 & 4.55 & 1.81 \\
\hline 46 & $\begin{array}{l}\text { Barros and } \\
\text { Ferreira [11] }\end{array}$ & 300 & 150 & 23 & 0.25 & CFRP & 0.34 & 3539 & 232 & 1.53 & 0.79 & 60 & 40 & 1.38 & 3.21 & 1.38 \\
\hline 47 & $\begin{array}{l}\text { Barros and } \\
\text { Ferreira [11] }\end{array}$ & 300 & 150 & 23 & 0.25 & CFRP & 0.57 & 3539 & 232 & 1.53 & 0.78 & 60 & 40 & 1.6 & 4.22 & 1.6 \\
\hline 48 & $\begin{array}{c}\text { Barros and } \\
\text { Ferreira [11] }\end{array}$ & 300 & 150 & 23 & 0.25 & CFRP & 0.53 & 3250 & 230 & 1.46 & 0.70 & 45 & 30 & 1.84 & 7.24 & 1.84 \\
\hline 49 & $\begin{array}{l}\text { Barros and } \\
\text { Ferreira [11] }\end{array}$ & 300 & 150 & 23 & 0.25 & CFRP & 0.88 & 3250 & 230 & 1.46 & 0.63 & 45 & 30 & 2.33 & 8.45 & 2.33 \\
\hline 50 & $\begin{array}{l}\text { Barros and } \\
\text { Ferreira [11] }\end{array}$ & 300 & 150 & 23 & 0.25 & CFRP & 0.53 & 3250 & 230 & 1.46 & 1.07 & 60 & 40 & 1.65 & 8.32 & 1.65 \\
\hline 51 & $\begin{array}{l}\text { Barros and } \\
\text { Ferreira [11] }\end{array}$ & 300 & 150 & 23 & 0.25 & CFRP & 0.88 & 3250 & 230 & 1.46 & 0.60 & 60 & 40 & 1.98 & 8.36 & 1.98 \\
\hline 52 & $\begin{array}{c}\text { Campione et al. } \\
{[19]}\end{array}$ & 300 & 150 & 43.75 & 0.2 & BFRP & 0.05 & 2100 & 90 & 2.8 & 1.54 & 100 & 60 & 1 & 1.13 & 0.85 \\
\hline 53 & $\begin{array}{c}\text { Campione et al. } \\
{[19]}\end{array}$ & 300 & 150 & 43.75 & 0.2 & BFRP & 0.05 & 2100 & 90 & 2.8 & 1.54 & 100 & 60 & 0.94 & 1.1 & 0.85 \\
\hline 54 & $\begin{array}{c}\text { Campione et al. } \\
{[19]}\end{array}$ & 300 & 150 & 43.75 & 0.2 & BFRP & 0.05 & 2100 & 90 & 2.8 & 1.54 & 100 & 60 & 0.91 & 1 & 0.85 \\
\hline
\end{tabular}




\begin{tabular}{|c|c|c|c|c|c|c|c|c|c|c|c|c|c|c|c|c|}
\hline 55 & $\begin{array}{c}\text { Campione et al. } \\
{[19]}\end{array}$ & 300 & 150 & 43.75 & 0.2 & BFRP & 0.16 & 2100 & 90 & 2.8 & 1.54 & 100 & 60 & 1.05 & 1.05 & 1.05 \\
\hline 56 & $\begin{array}{c}\text { Campione et al. } \\
{[19]}\end{array}$ & 300 & 150 & 43.75 & 0.2 & BFRP & 0.16 & 2100 & 90 & 2.8 & 1.54 & 100 & 60 & 0.98 & 1.1 & 0.98 \\
\hline 57 & $\begin{array}{c}\text { Campione et al. } \\
{[19]}\end{array}$ & 300 & 150 & 43.75 & 0.2 & BFRP & 0.16 & 2100 & 90 & 2.8 & 1.54 & 100 & 60 & 0.94 & 1.05 & 0.94 \\
\hline 58 & Wang [49] & 400 & 200 & 35.35 & 0.28 & CFRP & 0.17 & 4330 & 237 & 1.7 & 0.59 & 30 & 30 & 1.17 & 2.04 & 0.85 \\
\hline 59 & Wang [49] & 400 & 200 & 35.35 & 0.28 & CFRP & 0.17 & 4330 & 237 & 1.7 & 0.59 & 30 & 30 & 1.17 & 2.04 & 0.85 \\
\hline 60 & Wang [49] & 400 & 200 & 35.35 & 0.28 & CFRP & 0.33 & 4330 & 237 & 1.7 & 1.12 & 30 & 30 & 1.56 & 1.88 & 1.56 \\
\hline 61 & Wang [49] & 400 & 200 & 35.35 & 0.28 & CFRP & 0.33 & 4330 & 237 & 1.7 & 1.12 & 30 & 30 & 1.56 & 1.88 & 1.56 \\
\hline 62 & Wang [49] & 400 & 200 & 35.35 & 0.28 & CFRP & 0.50 & 4330 & 237 & 1.7 & 1.23 & 30 & 30 & 2.03 & 2.43 & 1.56 \\
\hline 63 & Wang [49] & 400 & 200 & 35.35 & 0.28 & CFRP & 0.50 & 4330 & 237 & 1.7 & 1.23 & 30 & 30 & 2.03 & 2.43 & 1.56 \\
\hline 64 & Wang [49] & 400 & 200 & 35.35 & 0.28 & CFRP & 0.33 & 4330 & 237 & 1.7 & 1.18 & 40 & 40 & 1.56 & 4.07 & 1.56 \\
\hline 65 & Wang [49] & 400 & 200 & 35.35 & 0.28 & CFRP & 0.33 & 4330 & 237 & 1.7 & 1.18 & 40 & 40 & 1.56 & 4.07 & 1.56 \\
\hline 66 & Wang [49] & 400 & 200 & 35.35 & 0.28 & CFRP & 0.33 & 4330 & 237 & 1.7 & 1.05 & 50 & 30 & 1.7 & 1.08 & 1.56 \\
\hline 67 & Wang [49] & 400 & 200 & 35.35 & 0.28 & CFRP & 0.33 & 4330 & 237 & 1.7 & 1.05 & 50 & 30 & 1.7 & 1.08 & 1.56 \\
\hline 68 & Wang [49] & 400 & 200 & 35.35 & 0.28 & CFRP & 0.33 & 4330 & 237 & 1.7 & 1.03 & 60 & 90 & 1.21 & 1.19 & 0.85 \\
\hline 69 & Wang [49] & 400 & 200 & 35.35 & 0.28 & CFRP & 0.33 & 4330 & 237 & 1.7 & 1.03 & 60 & 90 & 1.21 & 1.19 & 0.85 \\
\hline 70 & Wang [49] & 400 & 200 & 35.35 & 0.28 & CFRP & 0.17 & 4330 & 237 & 1.7 & 0.77 & 70 & 80 & 1.21 & 1.63 & 0.85 \\
\hline 71 & Wang [49] & 400 & 200 & 35.35 & 0.28 & CFRP & 0.17 & 4330 & 237 & 1.7 & 0.77 & 70 & 80 & 1.21 & 1.63 & 0.85 \\
\hline 72 & Wang [49] & 400 & 200 & 35.35 & 0.28 & CFRP & 0.33 & 4330 & 237 & 1.7 & 1.16 & 70 & 80 & 1.33 & 1.04 & 1.33 \\
\hline 73 & Wang [49] & 400 & 200 & 35.35 & 0.28 & CFRP & 0.33 & 4330 & 237 & 1.7 & 1.16 & 70 & 80 & 1.33 & 1.04 & 1.33 \\
\hline 74 & Wang [49] & 400 & 200 & 35.35 & 0.28 & CFRP & 0.50 & 4330 & 237 & 1.7 & 1.15 & 70 & 80 & 1.51 & 0.78 & 1.51 \\
\hline 75 & Wang [49] & 400 & 200 & 35.35 & 0.28 & CFRP & 0.50 & 4330 & 237 & 1.7 & 1.15 & 70 & 80 & 1.51 & 0.78 & 1.51 \\
\hline 76 & Yang [50] & 450 & 150 & 27.4 & 0.2 & CFRP & 0.17 & 3400 & 240 & 1.8 & 1.12 & 50 & 50 & 1.66 & 3.97 & 1.66 \\
\hline 77 & Yang [50] & 450 & 150 & 27.4 & 0.2 & CFRP & 0.17 & 3400 & 240 & 1.8 & 1.10 & 50 & 50 & 1.68 & 3.85 & 1.68 \\
\hline
\end{tabular}

Note: $H$ is the specimen height; $d$ is the specimen diameter; $f_{c o}$ is the unconfined concrete strength; $\varepsilon_{c o}$ is the corresponding axial strain at unconfined concrete strength; $t$ is the thickness of FRP jacket; $f_{f r p}$ is the ultimate tensile strength of FRP determined by coupon test; $E_{f r p}$ is the elastic modulus of FRP; $\varepsilon_{f r p}$ is the 
ultimate tensile strain of FRP determined by coupon test; $\varepsilon_{h, f r p}$ is the actual hoop rupture strain of FRP; $w$ is the FRP strip width; $s$ is the FRP strip gap; $f_{c c}$ is the peak strength of confined concrete; $\varepsilon_{c c}$ is the corresponding axial strain at peak strength; and $f_{c u}$ is the strength at ultimate strain. 
Table 4. Summary of Existing Stress-Strain Models for Partially FRP Confined Concrete

\begin{tabular}{|c|c|c|c|c|}
\hline Model & $k_{e}$ & Ultimate strength & Ultimate strain & $\begin{array}{l}\text { Effective hoop } \\
\text { rupture strain }\end{array}$ \\
\hline $\begin{array}{c}\text { Saadatmanesh et al. } \\
{[24]}\end{array}$ & $\left(1-\frac{s}{2 d}\right)^{2}$ & $\frac{f_{c c}}{f_{c o}}=-1.254+2.254 \sqrt{1+\frac{7.94 k_{e} f_{l}}{f_{c o}}}-2 \frac{k_{e} f_{l}}{f_{c o}}$ & $\frac{\varepsilon_{c c}}{\varepsilon_{c o}}=1+5\left(\frac{f_{c c}}{f_{c o}}-1\right)$ & No \\
\hline FIB [33] & $\left(1-\frac{s}{2 d}\right)^{2}$ & $\frac{f_{c c}}{f_{c o}}=0.2+3\left(\frac{k_{e} f_{l}}{f_{c o}}\right)^{0.5}$ & $\frac{\varepsilon_{c c}}{\varepsilon_{c o}}=2+1.25\left(\frac{E_{c}}{f_{c o}}\right)\left(\frac{k_{e} f_{l}}{f_{c o}}\right)^{0.5} \varepsilon_{f r p}$ & No \\
\hline Wu et al. [51] & No & $\begin{array}{c}\frac{f_{c c}}{f_{c o}}=0.745+3.357 \frac{f_{l}}{f_{c o}}-1.053\left(\frac{f_{l}}{f_{c o}}\right)^{2} \\
\text { or } \\
\frac{f_{c c}}{f_{c o}}=1+2 \frac{f_{l}}{f_{c o}}\end{array}$ & $\begin{array}{c}\varepsilon_{c u}=\frac{\varepsilon_{f r p}}{0.56 k_{1}\left(\frac{f_{l}}{f_{c o}}\right)^{-0.66}} \\
k_{1}=1 \text { if } E_{f r p} \leq 250 \mathrm{GPa} \\
k_{l}=\sqrt{\frac{250}{E_{f r p}}} \text { if } E_{f r p}>250 \mathrm{GPa}\end{array}$ & No \\
\hline $\begin{array}{c}\text { Barros and Ferreira } \\
{[11]}\end{array}$ & $\left(1-\frac{s}{2 d}\right)^{2}$ & $\begin{array}{l}\qquad \begin{array}{l}\frac{f_{c c}}{f_{c o}}=1+k_{1} \frac{k_{e} f_{l, a}}{f_{c o}} \quad k_{1}=a\left(\frac{k_{e} f_{l, a}}{f_{c o}}\right)^{-b} \\
\text { the values of } a \text { and } b \text { vary with } f_{c o}\end{array} \\
\text { for } \mathrm{C} 16 \text { and } 0.0025 \leq \rho_{f} \leq 0.0176 \text { : } \\
\qquad \begin{aligned} a & =2.9+72.848\left(\rho_{f}-0.0025\right) \\
b & =0.2177\end{aligned} \\
\text { for } \mathrm{C} 32 \text { and } 0.0025 \leq \rho_{f} \leq 0.0176 \text { : }\end{array}$ & $\begin{array}{l}\qquad \frac{\varepsilon_{c c}}{\varepsilon_{c o}}=1+k_{2}\left(\frac{f_{c c}}{f_{c o}}-1\right) \\
\text { values of } k_{2} \text { vary with } f_{c o} \\
\text { for C16 and } 0.0025 \leq \rho_{f} \leq 0.0176: \\
k_{2}=\left[555-29006\left(\rho_{f}-0.0025\right)\right] \varepsilon_{f}+2.0 \\
\text { for C32 and } 0.0025 \leq \rho_{f} \leq 0.0176: \\
k_{2}=\left[600-28695\left(\rho_{f}-0.0025\right)\right] \varepsilon_{f}+1.0\end{array}$ & Yes \\
\hline
\end{tabular}




\begin{tabular}{c}
$a=2.0+125.828\left(\rho_{f}-0.0025\right)$ \\
$b=0.42-7.947\left(\rho_{f}-0.0025\right)$ \\
\hline Pham et al. [20] $\left(1-\frac{s}{2 d}\right)^{2}$ \\
$\frac{f_{c c}}{f_{c o}}=1+3.3 k_{e} \frac{f_{l, a}}{f_{c o}}$
\end{tabular}

Note: $f_{l}$ is the nominal lateral confining pressure; $f_{l, a}$ is the actual lateral confining pressure; and $f_{f e}$ is the actual rupture strength of FRP. 


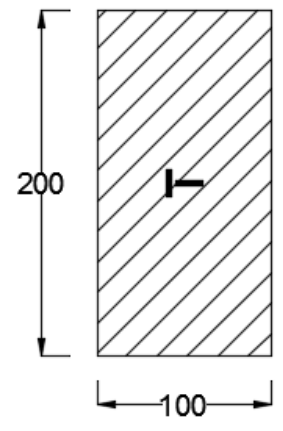

(a) $\mathrm{S} 0$

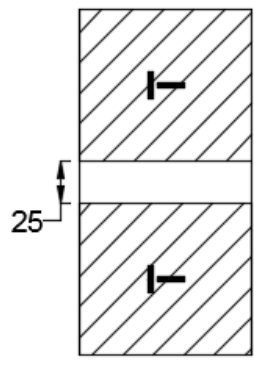

(b) $\mathrm{S} 25$

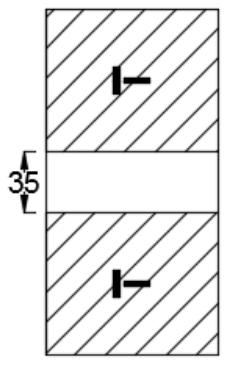

(c) $\mathrm{S} 35$

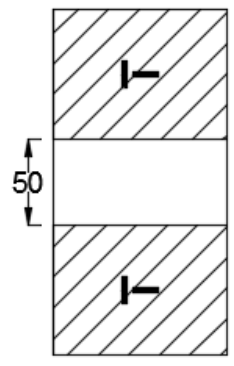

(d) $\mathrm{S} 50$

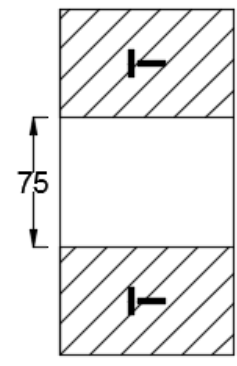

(e) S75

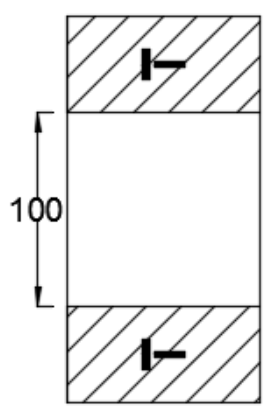

(f) $\mathrm{S} 100$

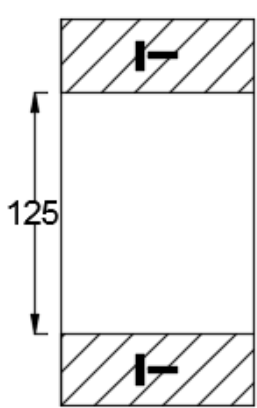

(g) S125

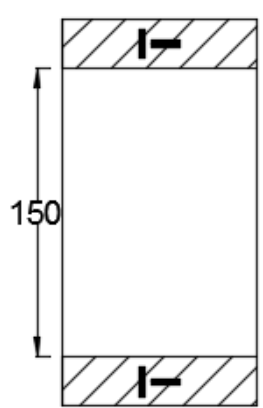

(h) S150

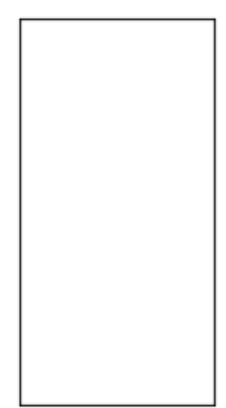

(i) $\mathrm{S} 200$

Fig. 1. Wrapping configurations (all units in $\mathrm{mm}$ ) 


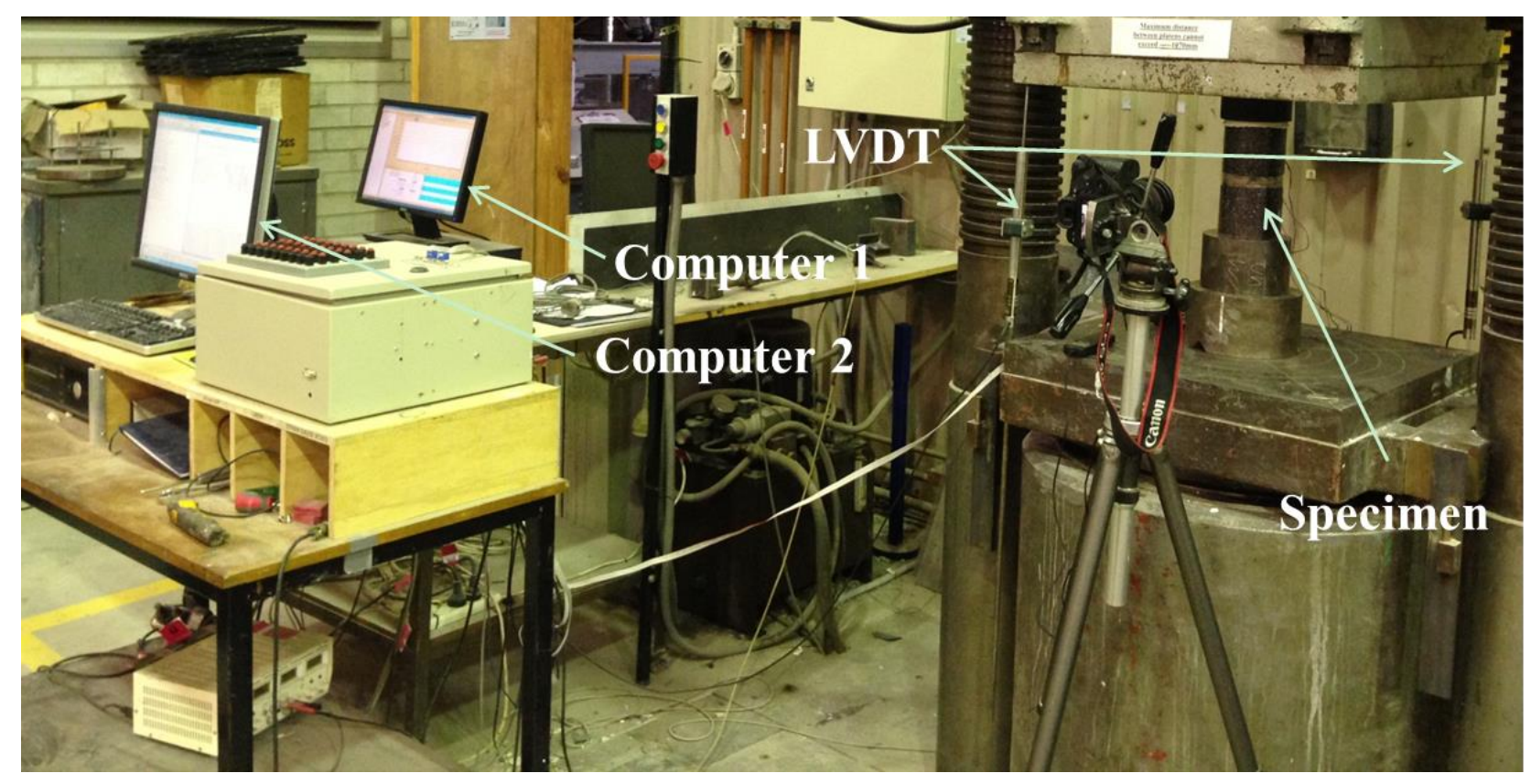

Fig. 2. Test setup 


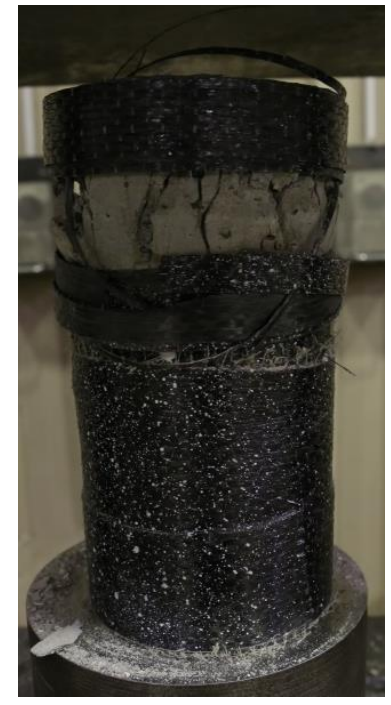

(a) $\mathrm{S} 0$

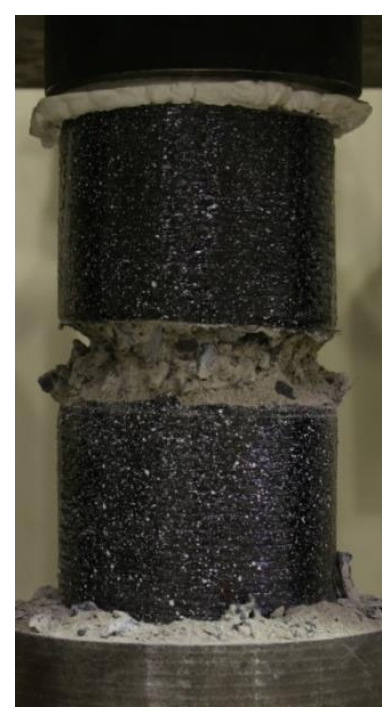

Phase 1
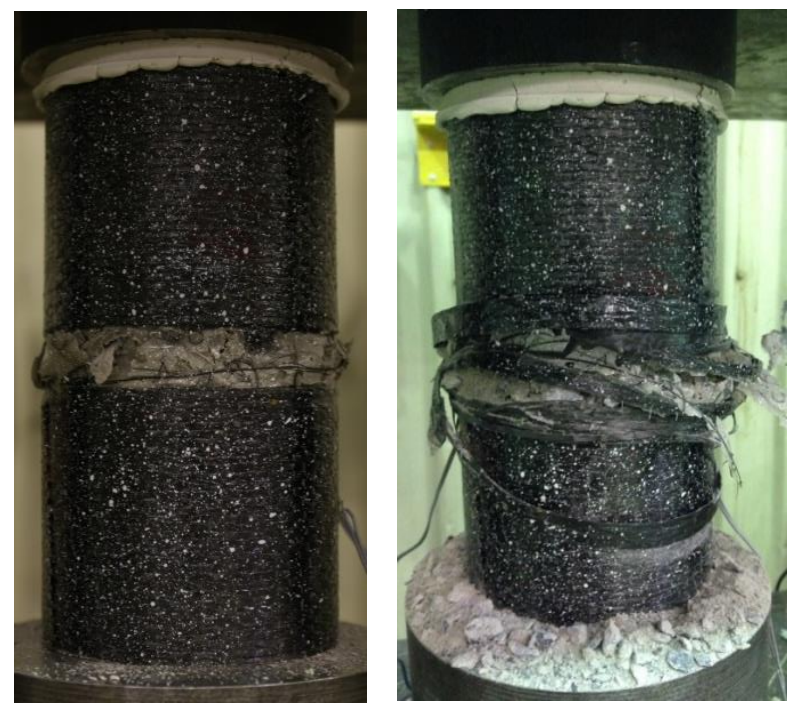

(b) S25

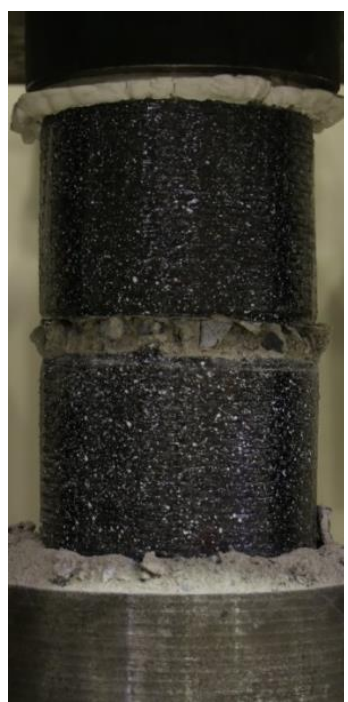

Phase 2

(c) S35

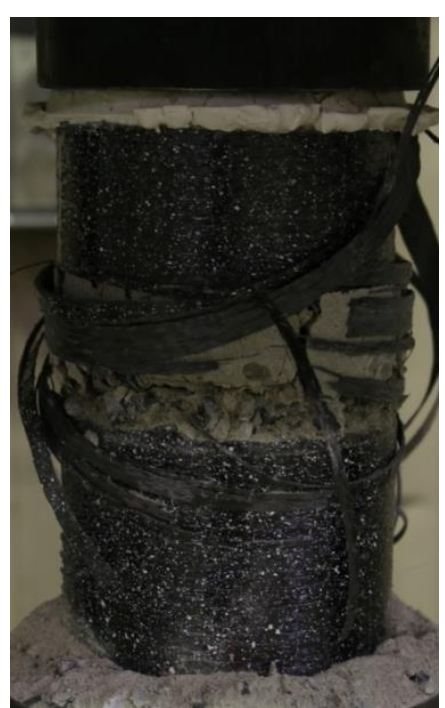

Phase 3 


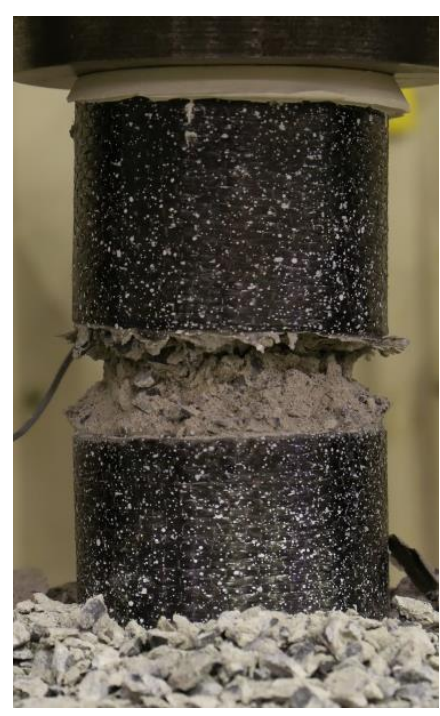

(d) $\mathrm{S} 50$

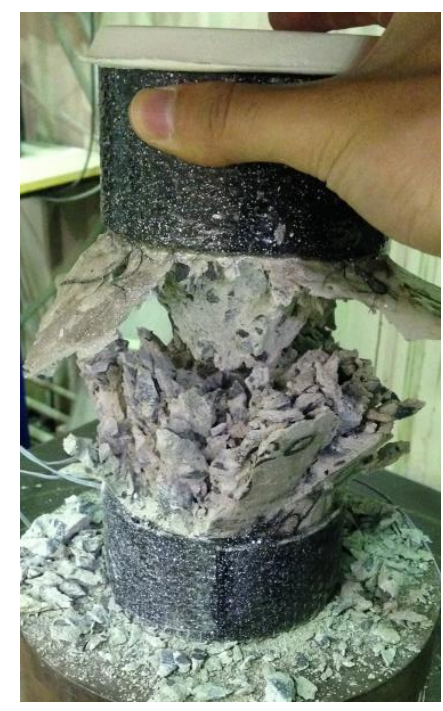

(f) $\mathrm{S} 100$
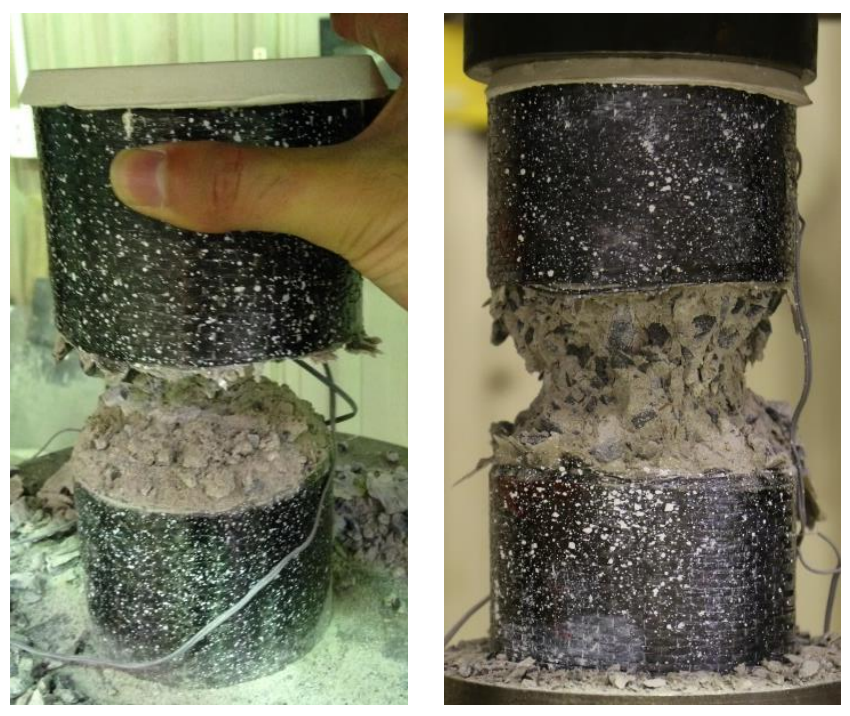

(e) $\mathrm{S} 75$

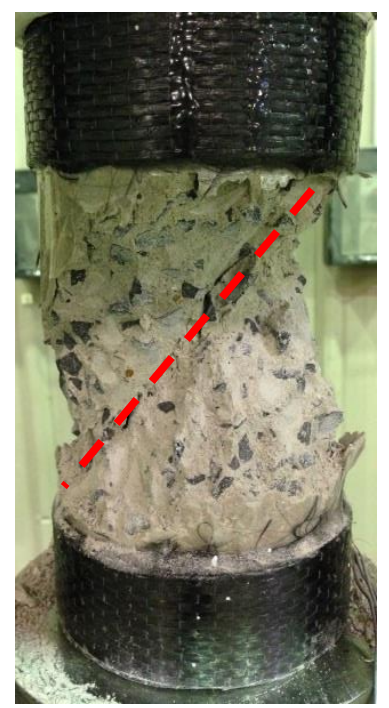

(g) S125

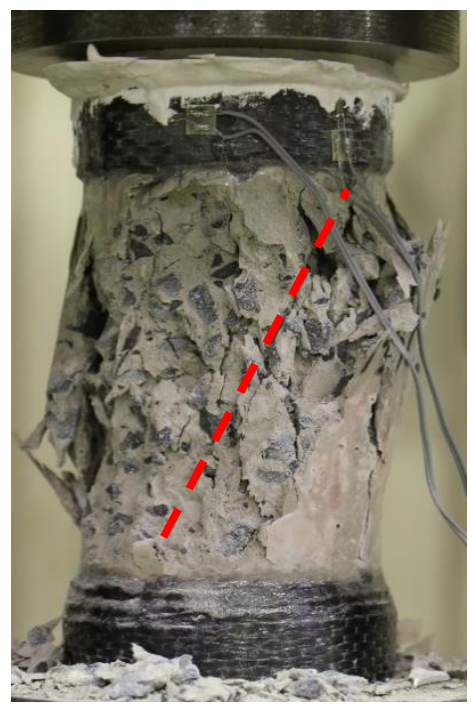

(h) $\mathrm{S} 150$

Fig. 3. Failure modes 


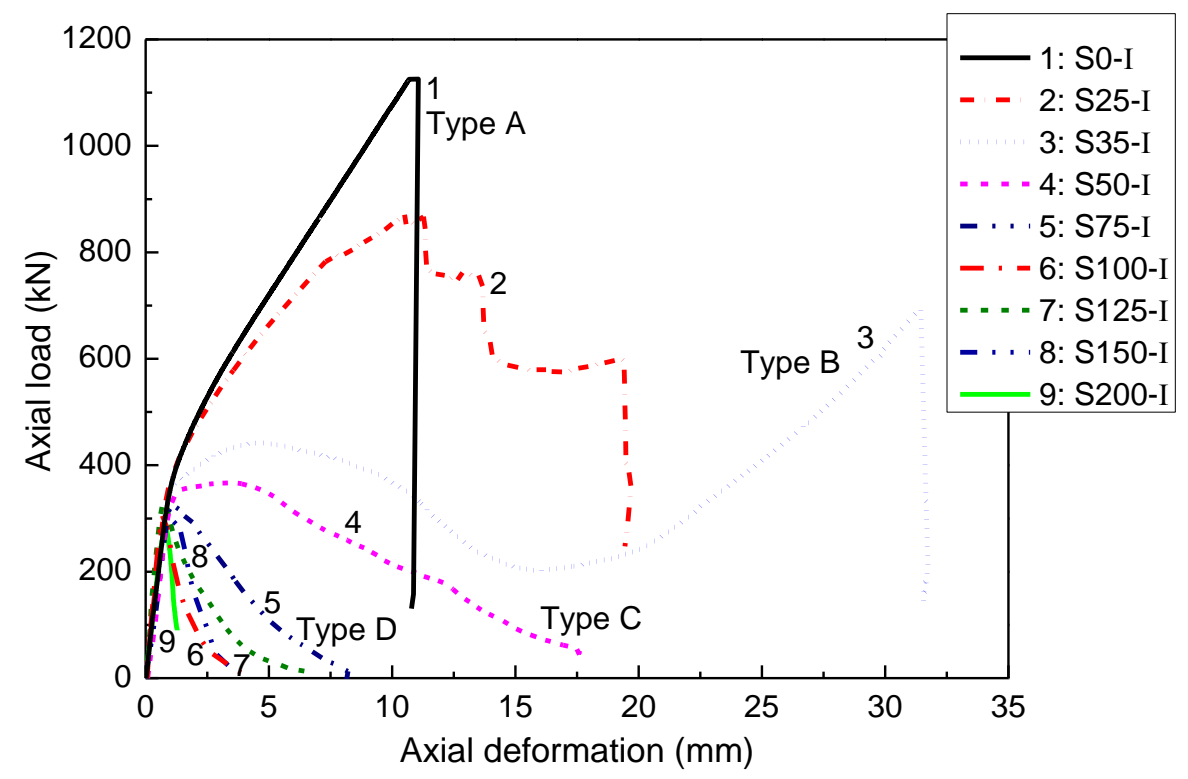

(a) First specimen in each group (Specimen I)

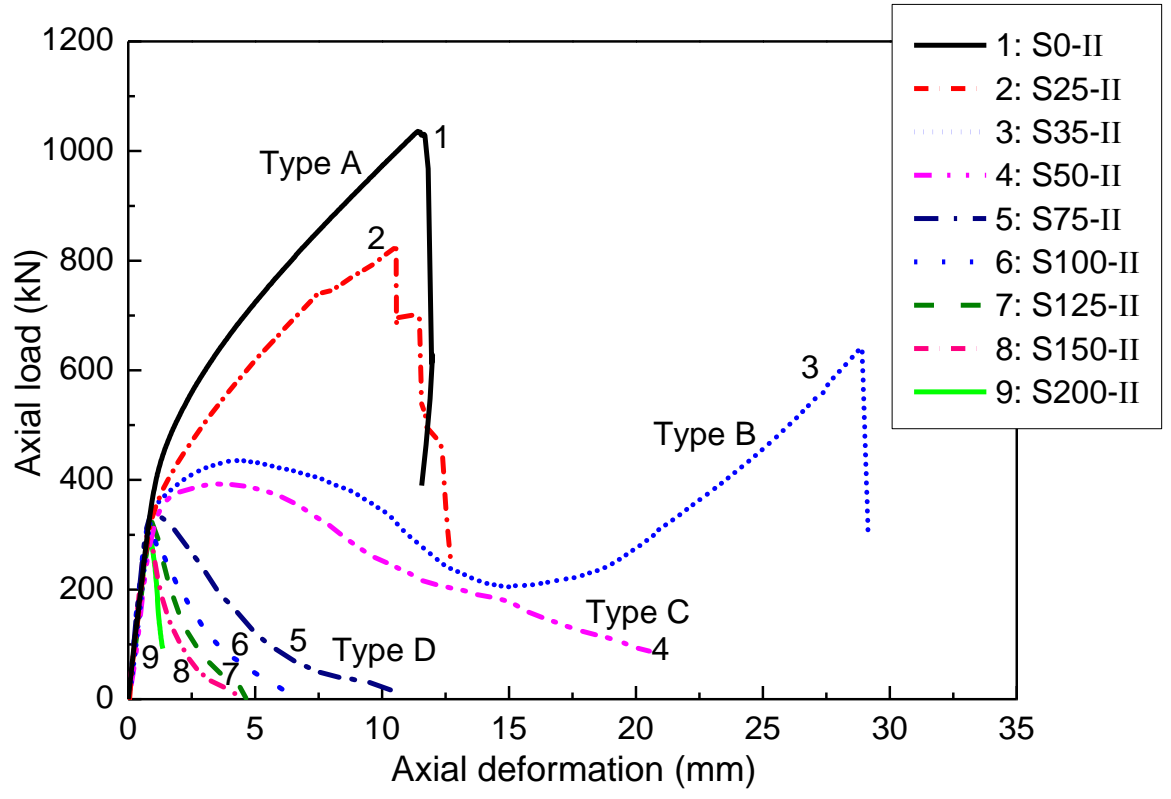

(b) Second specimen in each group (Specimen II)

Fig. 4. Axial load-axial deformation behavior of specimens 


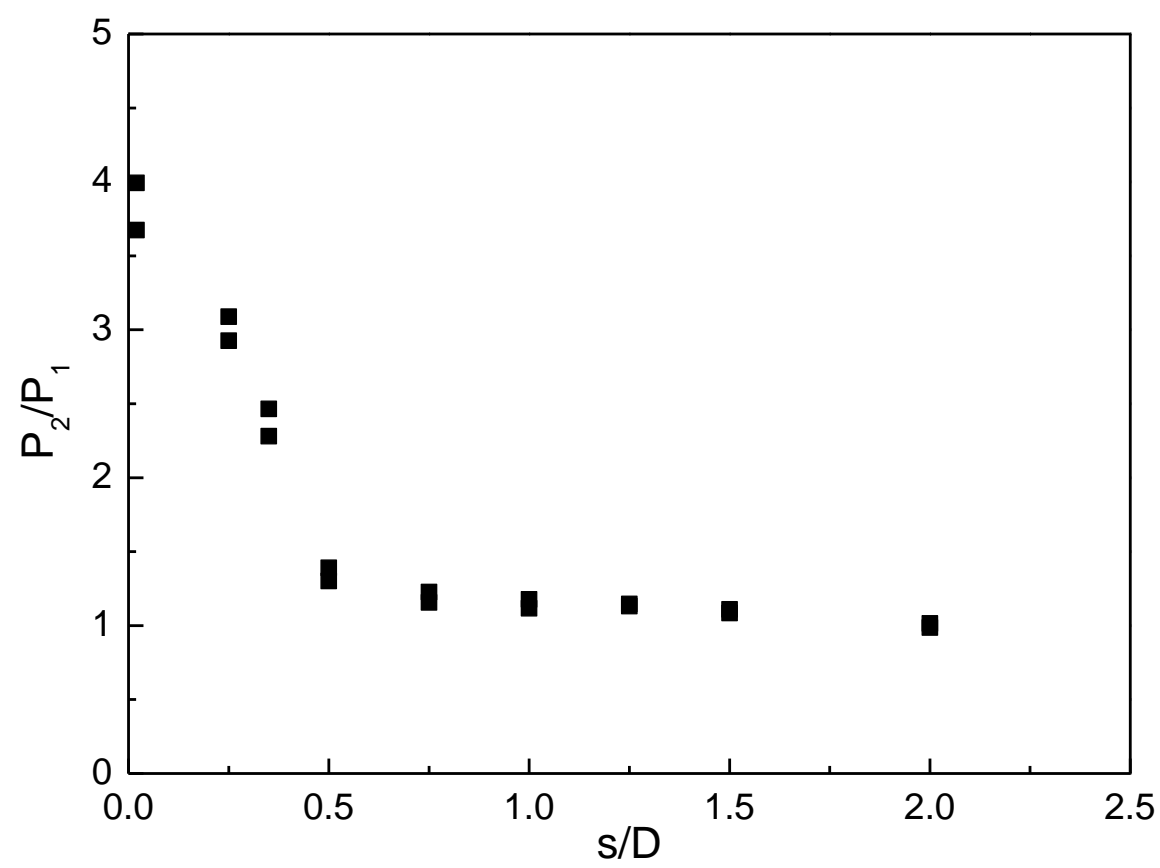

Fig. 5. Influence of s/D ratio on the $\mathrm{P}_{2} / \mathrm{P}_{1}$ ratio (Note: s/D indicates spacing to diameter ratio; $\mathrm{P}_{2} / \mathrm{P}_{1}$ indicates load enhancement ratio, in which $\mathrm{P}_{1}$ and $\mathrm{P}_{2}$ indicate the ultimate loads for confined and unconfined concrete specimens, respectively) 


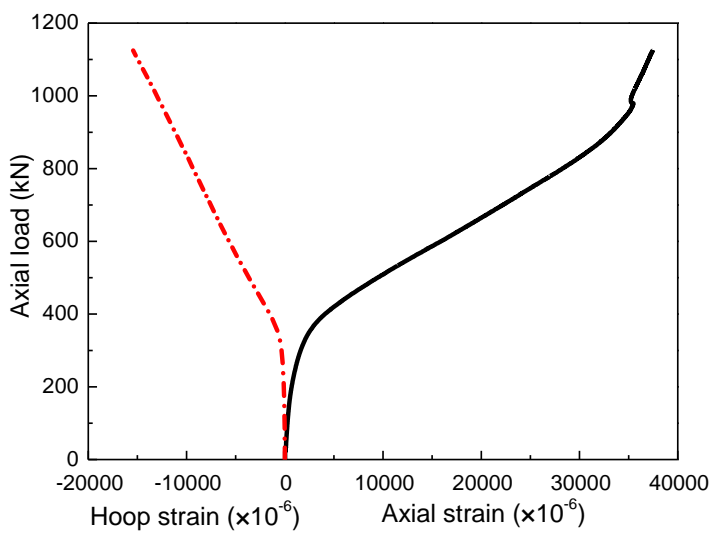

(a) S0

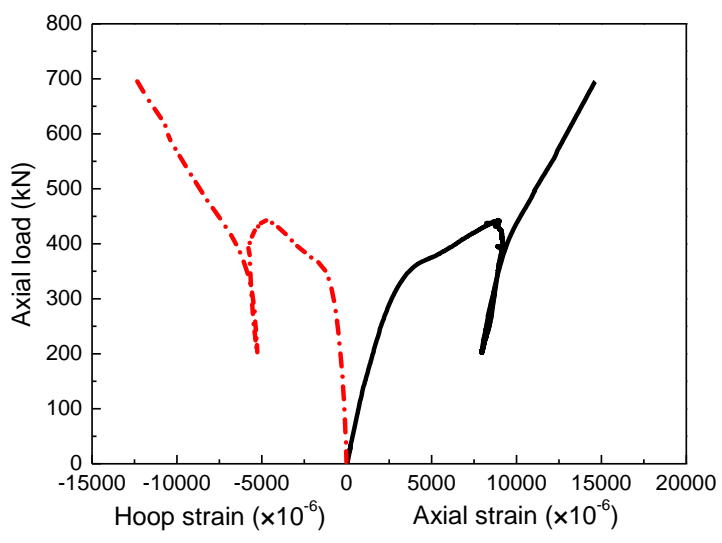

(c) $\mathrm{S} 35$

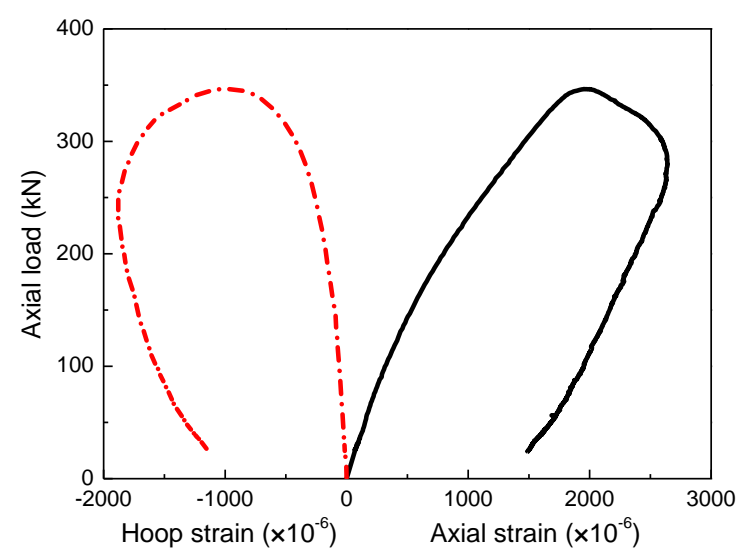

(e) S75

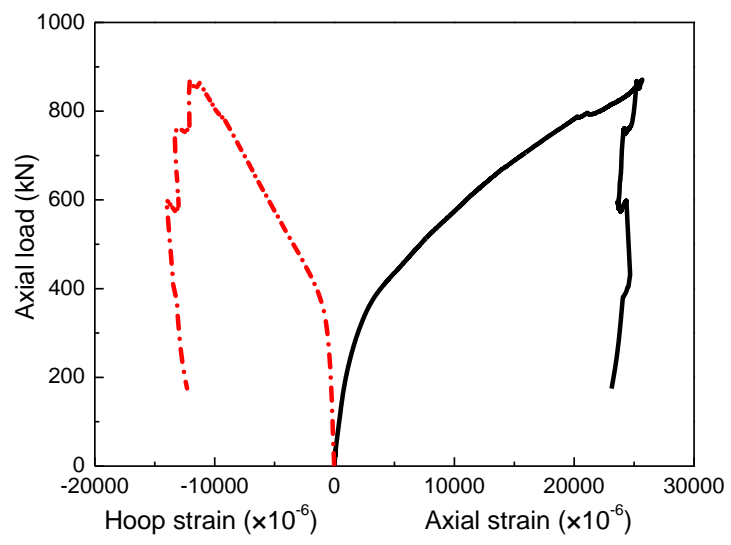

(b) $\mathrm{S} 25$

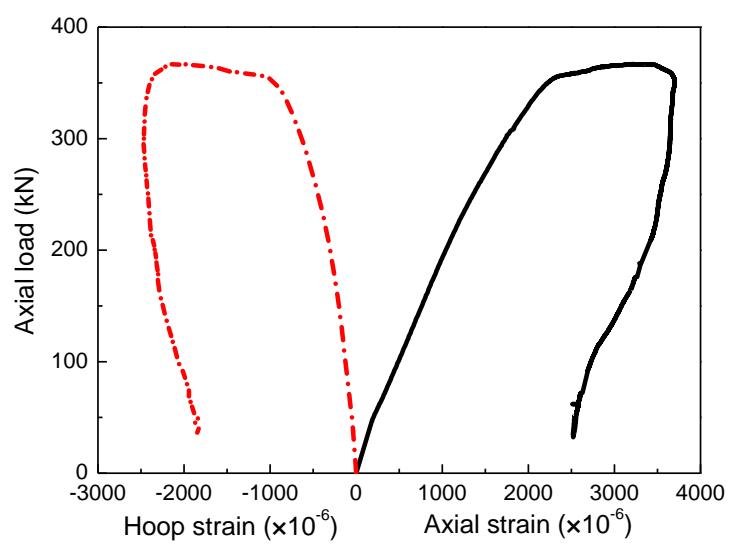

(d) $\mathrm{S} 50$

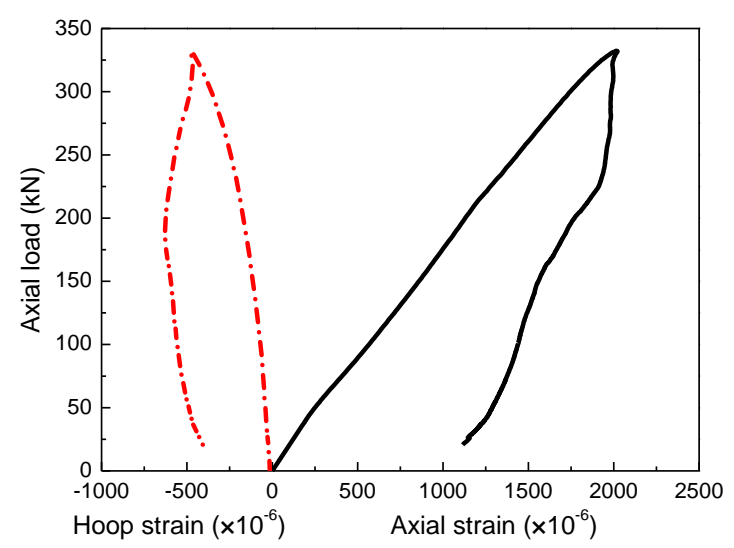

(f) $\mathrm{S} 100$ 


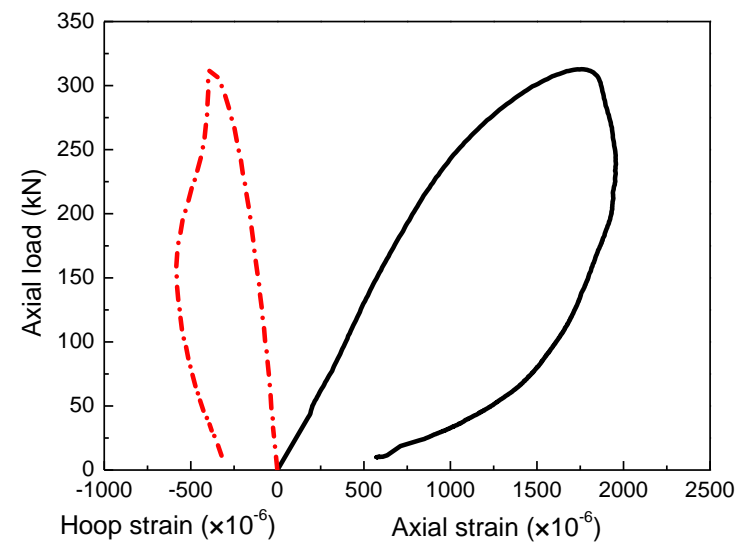

(g) S150

Fig. 6. Axial load-strain relationships (strain gauge readings were taken from FRP strips) 


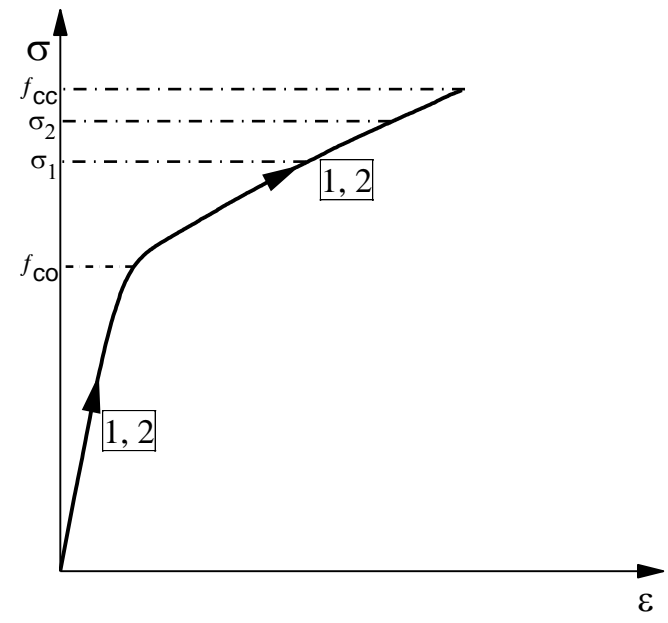

(a) Specimens with Type A behavior

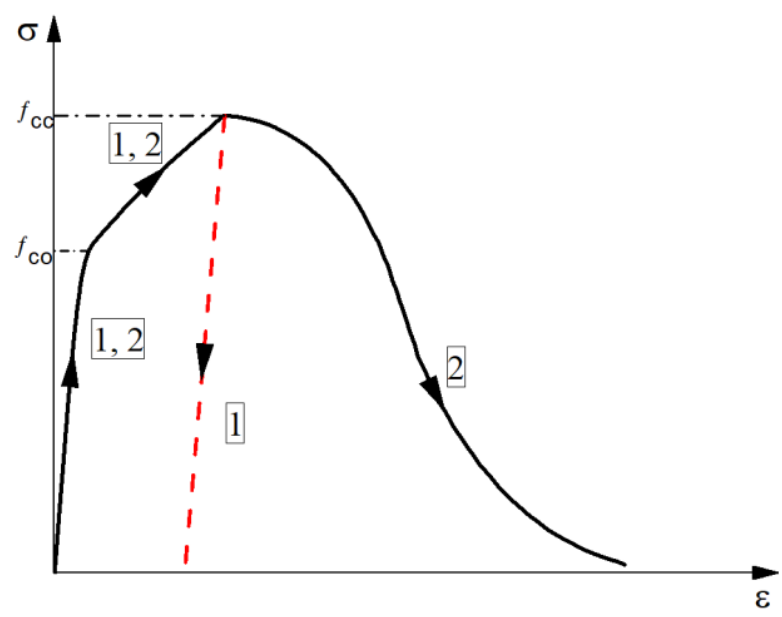

(c) Specimens with Type $\mathrm{C}$ behavior

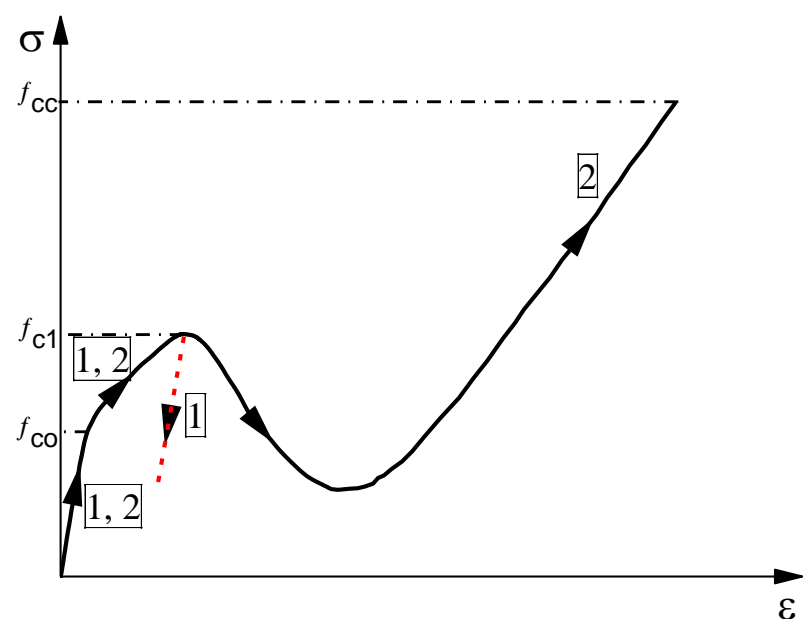

(b) Specimens with Type B behavior

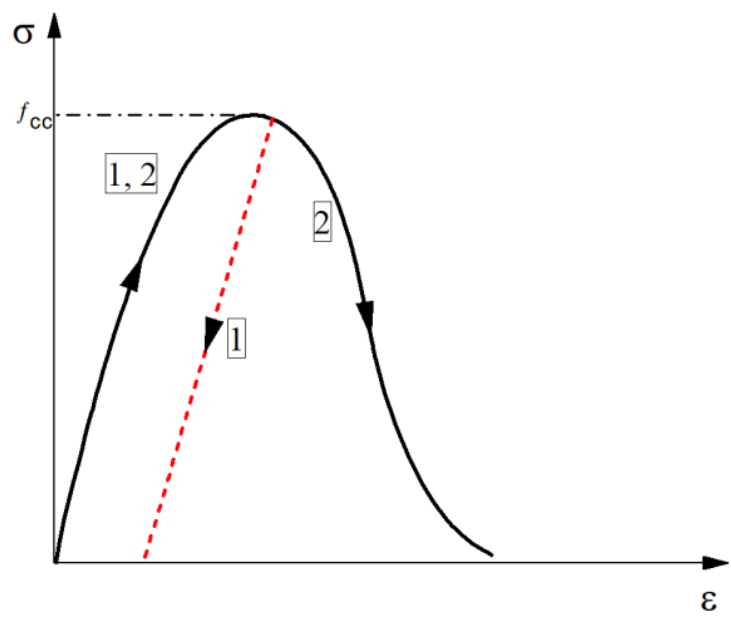

(d) Specimens with Type D behavior

Fig. 7. Axial stress-axial strain behaviors of wrapped and non-wrapped concrete $(1)$ indicates the stress-strain behavior of wrapped concrete, and 2 indicates the stress-strain behavior of non-wrapped concrete; $\sigma_{1}$ and $\sigma_{2}$ indicate the axial stress of wrapped and non-wrapped concrete, respectively, at the same time) 


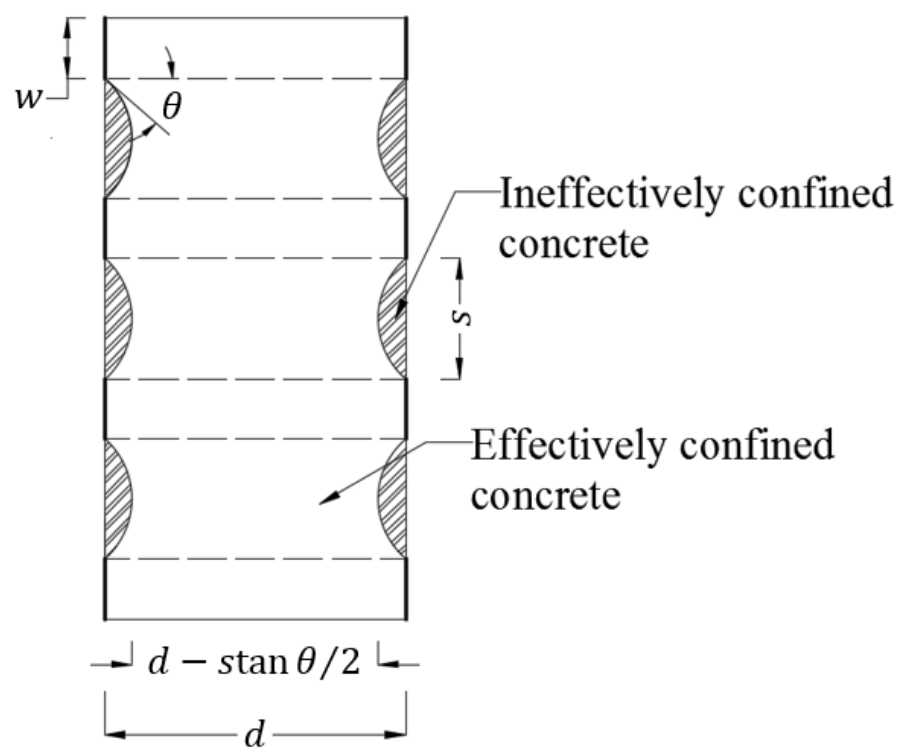

Fig. 8. Partial confinement mechanism 


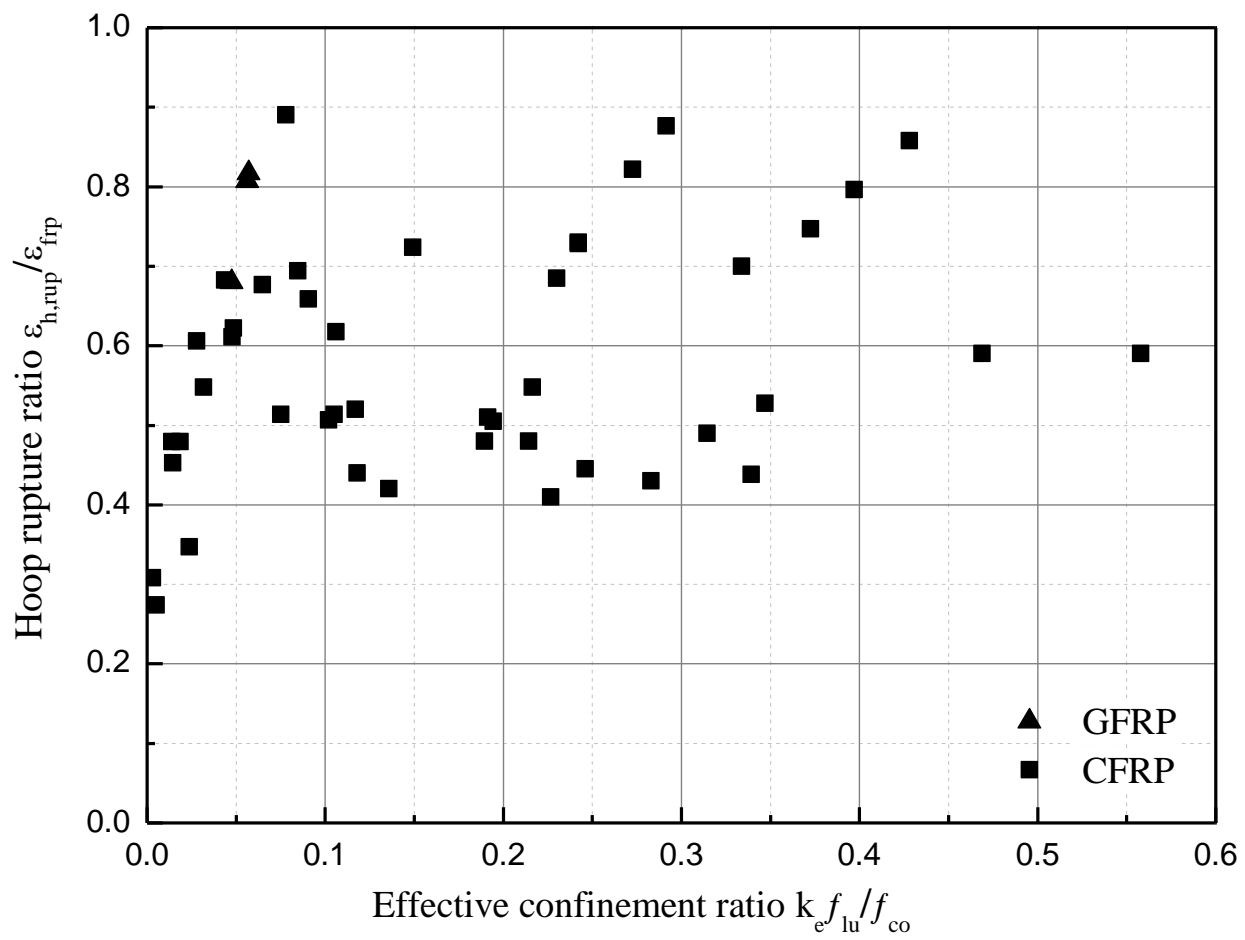

Fig. 9. Hoop rupture strain of FRP with different effective confinement ratio 

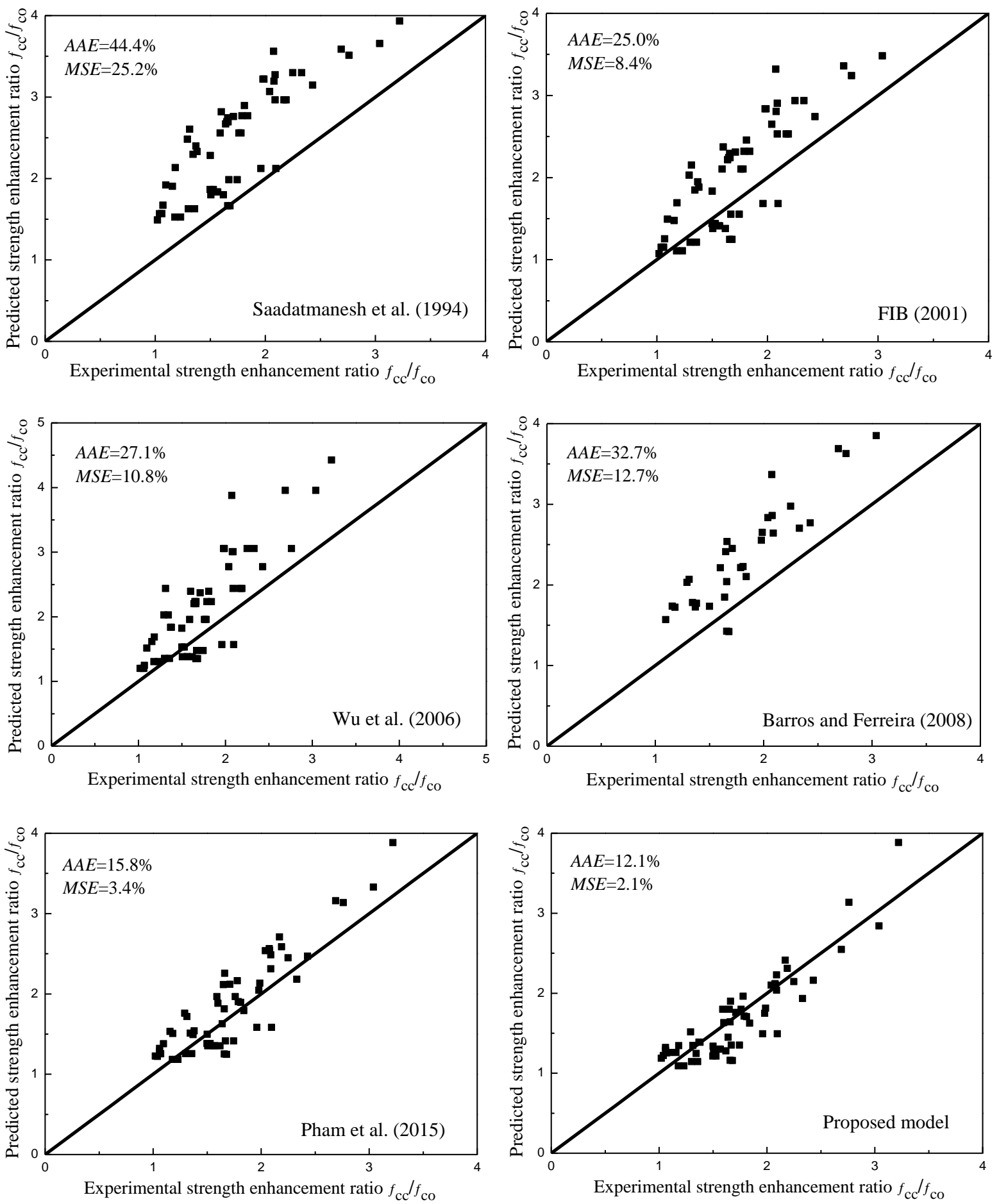

Fig. 10. Performance of models for ultimate strength prediction 

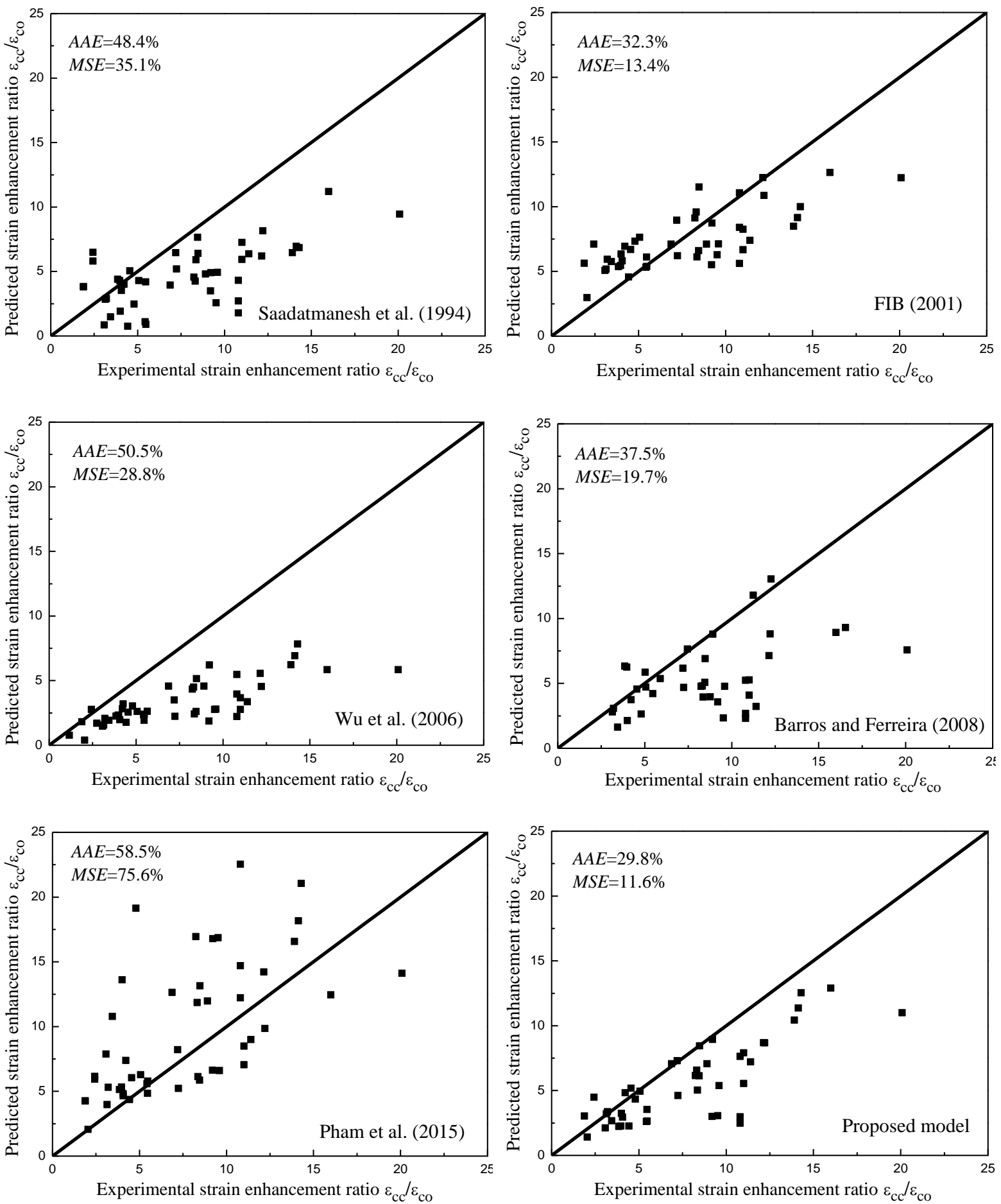

Fig. 11. Performance of models for ultimate strain prediction 